\title{
Significance of the Nova Brasilândia metasedimentary belt in western Brazil: Redefining the Mesoproterozoic boundary of the Amazon craton
}

\author{
Eric Tohver, ${ }^{1,2}$ Ben van der Pluijm, ${ }^{1}$ Klaus Mezger ${ }^{3}$ Eric Essene, ${ }^{1}$ Jaime Scandolara, ${ }^{4}$ \\ and Gilmar Rizzotto ${ }^{4}$ \\ Received 18 July 2003; revised 6 July 2004; accepted 16 September 2004; published 7 December 2004.
}

[1] The Nova Brasilândia metasedimentary belt (NBMB) of western Brazil marks a fundamental crustal boundary in the Amazon craton. The metasedimentary rocks of the NBMB (calc-silicates, metapelites, quartzites, metabasites) contrast strongly with the older, polycyclic granitoid rocks of the adjacent Amazon craton. Aeromagnetic anomalies indicate that the belt is continuous for at least $1000 \mathrm{~km}$ in an $\mathrm{E}-\mathrm{W}$ direction, although the easternmost extent of the NBMB is covered by the Cretaceous sediments of the Parecis Formation. Additional geologic evidence suggests that the belt extends along an E-W trend for $\sim 2000 \mathrm{~km}$. The northern portion of the NBMB preserves vestiges of an early high pressure-temperature (P-T) assemblage (kyanite + staurolite) overprinted by sillimanite during prograde metamorphism. A higher metamorphic grade is observed in the southern portion of the belt, with peak conditions calculated to be $800 \mathrm{MPa}$ and $800^{\circ} \mathrm{C}$ for granulitic assemblages. The combined P-T path demonstrates that the competing processes of imbrication (northern domain) and magma generation (southern domain) are responsible for regional metamorphism and crustal thickening. Cooling from peak metamorphic conditions is recorded by $\mathrm{U}-\mathrm{Pb}$ monazite ages of $1090 \mathrm{Ma}$ and titanite ages of $\sim 1060 \mathrm{Ma}$. Integrated cooling rates of $2^{\circ}-3^{\circ} \mathrm{C} / \mathrm{Myr}$ from regional metamorphism are calculated from these $\mathrm{U} / \mathrm{Pb}$ ages combined with ${ }^{40} \mathrm{Ar}{ }^{39} \mathrm{Ar}$ ages of hornblende $(\sim 970 \mathrm{Ma})$ and biotite ( $\sim 910 \mathrm{Ma})$. The NBMB marks the Mesoproterozoic limit of the SW Amazon craton. The discordance of the NBMB to the NNW structural trend of the younger Aguapeí belt (200 km SE of NBMB), together with marked differences between the two

\footnotetext{
${ }^{1}$ Department of Geological Sciences, University of Michigan, Ann Arbor, Michigan, USA.

${ }^{2}$ Now at the Instituto de Geociências (GMG), Universidade de São Paulo, Cidade Universitária, São Paulo, SP Brazil.

${ }^{3}$ Institut für Mineralogie, Universität Münster, Münster, Germany.

${ }^{4}$ Companhia de Pesquisas de Recursos Minerais (CPRM), Porto Velho, RO Brazil.

Copyright 2004 by the American Geophysical Union. 0278-7407/04/2003TC001563
}

belts in sedimentary environment, metamorphic grade, and timing of deformation, signify that these two belts are not geologically continuous. The "Grenvillian" deformation recorded by the NBMB belt marks the final docking of the Amazon craton and Paragua craton within the Rodinia framework. The Aguapeí belt, in contrast, seems to record only limited deformation internal to the Paragua craton. INDEX TERMS: 8102 Tectonophysics: Continental contractional orogenic belts; 3660 Mineralogy and Petrology: Metamorphic petrology; 1035 Geochemistry: Geochronology; 8025 Structural Geology: Mesoscopic fabrics; 9360 Information Related to Geographic Region: South America; KEYWORDS: Rodinia, Grenville mobile belt, Amazon craton, Paragua craton, geochronology, P-T path. Citation: Tohver, E., B. van der Pluijm, K. Mezger, E. Essene, J. Scandolara, and G. Rizzotto (2004), Significance of the Nova Brasilândia metasedimentary belt in western Brazil: Redefining the Mesoproterozoic boundary of the Amazon craton, Tectonics, 23, TC6004, doi:10.1029/2003TC001563.

\section{Introduction}

[2] Many recent plate reconstructions for the Mesoproterozoic postulate that the Grenville orogeny represents worldwide events leading to the assembly of the supercontinent Rodinia [Dalziel, 1991; Hoffman, 1991]. North America holds a keystone position in Rodinia based on the Neoproterozoic rift basins that circumscribe Laurentia [Bond et al., 1984], with most reconstructions placing the southwestern margin of Amazonia in proximity to some portion of eastern Laurentia. The Grenvillian history of the eastern Laurentian margin has been relatively well documented along the $\sim 3000 \mathrm{~km}$ length of this ancient mobile belt, which stretches from the southernmost portion of cratonic Laurentia typified by the Llano Uplift region of central Texas [Mosher, 1998] to the northeastern exposures of Labrador [Krogh, 1994; Davidson, 1998]. In contrast, present knowledge of the Grenvillian history of the Amazon craton is less complete, making exposed portions of the belts all the more interesting from the standpoint of Rodinia paleogeography.

[3] Three positions have been proposed for the Mesoproterozoic paleogeography of the Amazonia-Laurentia connection within Rodinia, based on different lines of evidence. Hoffman [1991] and Sadowski and Bettencourt [1996] used broad geological similarities, such as igneous age provinces or metamorphic ages, to pair Amazonia with the central Grenville Province of Ontario and New York at a 
later interval, circa 1.0 Ga. Dalziel [1991] chose a more northerly position for Amazonia alongside Newfoundland and Labrador, based largely on matching the Iapetan rifting histories of Laurentia with the Precordilleran margin of South America [Bond et al., 1984], which is now recognized to constitute a separate terrane, exotic to South America [Thomas and Astini, 1996]. New paleomagnetic data for the early "Grenvillian" interval (circa 1.2 Ga) of the Amazon craton supports a collision with the southernmost portion of Laurentia, i.e., the Llano region of central Texas [Tohver et al., 2002]. Observations of large-scale strike-slip deformation of the Amazon craton basement rocks, together with observations from Laurentia, suggest large-scale displacement between Amazon and Laurentia, possibly reconciling the Hoffman [1991] and Tohver et al. [2002] paleographic models. According to this transpressive model of Grenville orogenesis, the evolution of Rodinia was marked by both thrust faulting and strike-slip tectonics along the greater Grenville collisional zone, comprised of both its North and South American equivalents.

[4] One of the principal tasks in placing Amazonia in a Rodinian reference frame is identifying the craton's principal structures, particularly those that are relevant to its Meso/ Neoproterozoic history. The classical work of Almeida and Hasui [1984] defines the Amazon craton at its southern and eastern margins by the presence of Brasiliano/Panafrican belts (double black line, Figure 1, bottom inset). However, the emphasis on structures related to Gondwanan history distracts from the somewhat older signs of a previous supercontinent, thus obscuring the role of Amazonia in the constructive phase of Rodinian history. We contend that the Meso/Neoproterozoic cratonic margin of Amazonia is such a structure overlooked by the traditional model. In this contribution, new geochronological, petrological, and structural data from the Nova Brasilândia Metasedimentary belt (NBMB) are presented as evidence of high-grade deformation under transpressive conditions during late Mesoproterozoic times. Previously published aeromagnetic data from this belt suggest that lithological and structural trends in the NBMB continue from the study region $\sim 1000 \mathrm{~km}$ to the eastern limit of the Amazon craton, the Brasiliano-aged Paraguai belt. This eastern portion of the belt is entirely covered by the Mesozoic sediments of the Parecis Formation [Barros et al., 1978]. Approximately $750 \mathrm{~km}$ to the west, $\mathrm{K}$-Ar geochronology on borehole samples of the metasedimentary basement underlying the Phanerozoic sediments in the westernmost Amazon basin on the Brazil/Peru border yields ages (circa $1.0 \mathrm{Ga}$ ) similar to those observed in our study region [Amaral, 1974]. Thus the study area is the exposed representative of a geological belt at least $2000 \mathrm{Km}$ in extent. We propose that this belt marks the limit of the Amazon craton during the late Mesoproterozoic, deformed in the studied region by the emplacement of the Paragua block during the final amalgamation of the Rodinia supercontinent.

\section{Regional Geology}

[5] The southwestern margin of the present-day Amazon craton is marked by three different Grenvillian belts: the
Sunsás and Aguapeí belts exposed in eastern Bolivia and along the Bolivia-Brazil border, respectively; and the Nova Brasilândia belt exposed in southern Rondônia (Figure 1). The former two belts have been interpreted as delimiting the Paragua craton, a polycyclic block of at least Paleoproterozoic age and of subcontinental dimensions exposed almost exclusively in eastern Bolivia [Litherland et al., 1986; Saes, 1999; Geraldes et al., 2001]. The interior of this block is characterized by the preservation of K-Ar ages and older structural trends considered to mark the end of cratonization at circa 1.3 Ga [Litherland et al., 1989]. The SunsásAguapeí belts comprise quartzitic and conglomeratic units deformed during late Grenvillian (circa $1.0 \mathrm{Ga}$ ) times. Stratigraphic correlations between the Sunsás and Vibosi groups of Bolivia and the Aguapeí Group of Brazil have been advanced on the basis of lithology [Litherland et al., 1989; Saes, 1999], with recent SHRIMP dates from the bottom of the Aguapeí sequence exposed in Mato Grosso, Brazil, suggesting a maximum depositional age of $1231 \pm$ 14 Ma [Santos et al., 2001]. Deformation of the Sunsás belt is manifested in a network of curvilinear, strike-slip shear zones, with mylonitic belts observed in an en echelon trend that generally strikes WNW. Extensive granitic intrusions accompany the deformation of the Sunsás belt along these mylonitic belts, followed by many postkinematic granites [Litherland et al., 1986, 1989]. In contrast, magmatism is almost entirely absent from the Aguapeí belt, which is marked by greenschist facies mylonites generated during thrusting and strike-slip deformation along its NNW trend [Barros et al., 1978] with minor S-type granite magmatism [Geraldes et al., 2001]. Compared to the Sunsás belt, only localized deformation affected the Aguapeí belt (Figure 2a), with the external margins of the belt (Serrania Huanchaca in the west and Rio Branco in the east) still displaying horizontal or gently folded bedding of preorogenic strata [Litherland and Power, 1989; Saes, 1999; Fernandes, 1999]. Assuming that the lithostratigraphic correlation between the units exposed in these localities is valid, the total width of the Aguapeí belt is only $\sim 50 \mathrm{~km}[$ Saes, 1999].

[6] The Nova Brasilândia Metasedimentary belt lies $\sim 200 \mathrm{~km}$ to the NNW from the Aguapeí belt in the Brazilian state of Rondônia. There is no apparent structural continuity between the E-W trending NBMB and the northernmost extent of the NNW trending Aguapeí belt. The NBMB was believed to be a preserved RondônianoSan Ignacio (1.3-1.5 Ga) feature of the Paragua block, and was referred to as the Comemoração schists by Litherland et al. [1986]. Later workers in the Amazon craton incorporated these conclusions by linking age provinces across the NBMB, effectively including the Paragua craton as part of the Amazon craton [e.g., Tassinari and Macambira, 1999; Tassinari et al., 2000; Santos et al., 2000; Geraldes et al., 2001]. The deep-water sediments of the NBMB (carbonates intercalated with fine-grained pelitic and sandy units) are lithologically distinct from the mature, continental sediments of the Aguapeí and Sunsás Groups. In spite of the high metamorphic grade of much of the belt (amphibolite to granulite), locally preserved $\mathrm{S}_{0}$ bedding is still distinguish- 


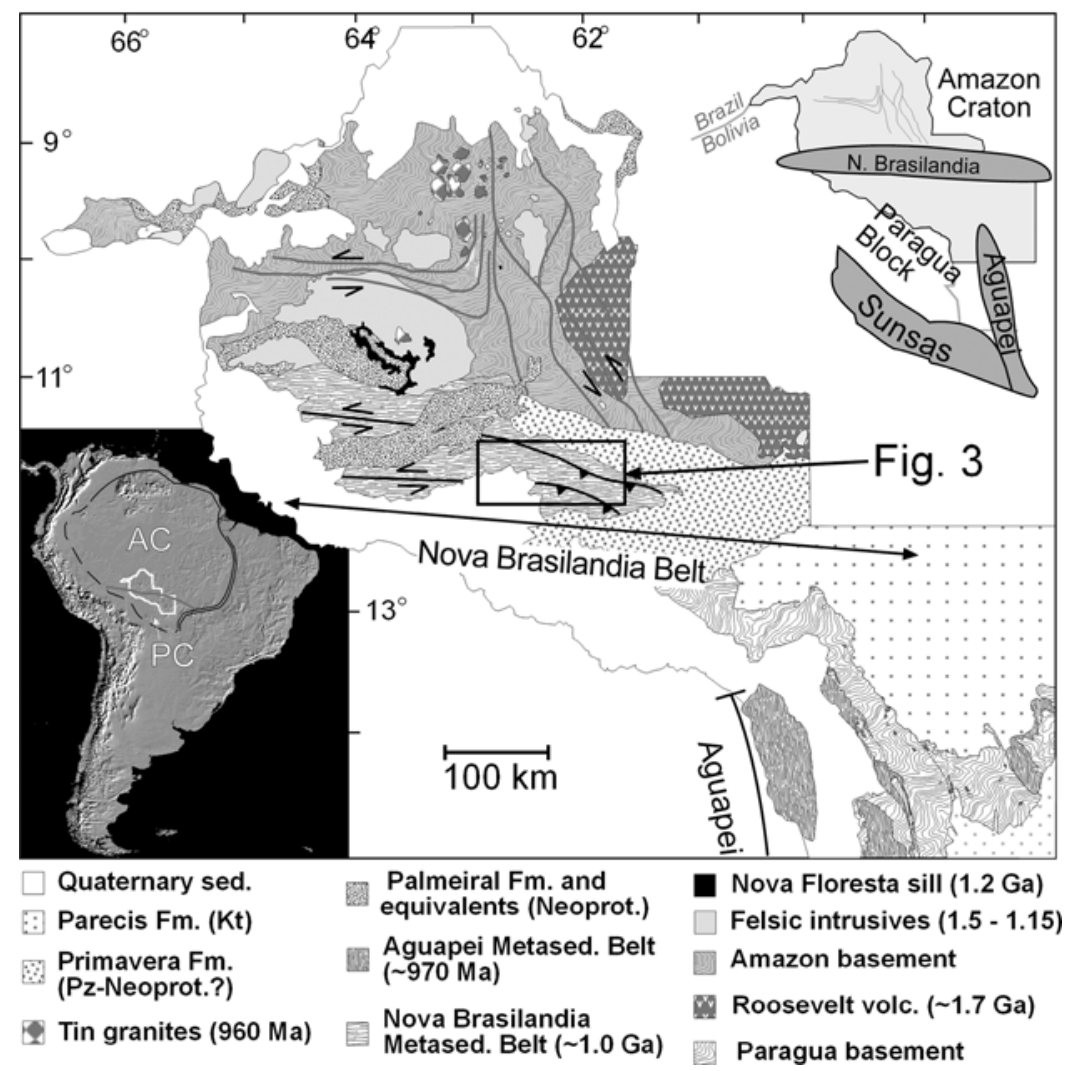

Figure 1. (bottom inset) Map of location of study region (white outline) in South American continent. Amazon craton is shown in black line, dashed where uncertain. The double black line indicates the presence of Brasiliano/Panafrican mobile belts and the gray, bold line indicates the location of the proposed division between the Amazon craton (AC) and the Paragua craton (PC). (top inset) Gray area outlined in black is area depicted in main image. Bold gray line is the international border between Bolivia and Brazil. Generalized geometry of "Grenvillian" belt of SW Amazon region shown with Sunsás belt forming southern boundary of Paragua craton, the limits of which are ill defined to the east and west. The northern boundary of the Paragua craton is proposed to be the E-W trending Nova Brasilândia belt, not shown in its full extent here. North of the Nova Brasilândia belt lie the polycyclic rocks of Amazon craton. Note the disjunctive trends between the Aguapeí belt and the Nova Brasilândia belt. (main) Simplified geological of the Brazilian state of Rondônia and westernmost Mato Grosso. Older "Grenvillian" deformation at circa 1.2 Ga created the shear zone network in Amazon craton basement rocks shown in bold gray lines. The boundary between the Amazon craton and the metasediments of the Nova Brasilândia belt is covered by three sedimentary sequences (Palmeiral Formation, Primavera Group, and Parecis Formation), which follow the east-west trend of the belt itself. Bold, black lines in Nova Brasilândia belt indicate major mylonitic zones developed during circa $1.09 \mathrm{Ga}$ metamorphism.

able in some outcrops, where a repetitive sequence of pelitic layers interbedded with quartzose layers suggests a turbiditic environment [Rizzotto, 1999]. Metamorphosed mafic rocks are observed mainly as massive amphibolite units, which locally preserve mafic cumulate textures. SHRIMP analysis of detrital zircons from the pelitic rocks in this sequence yield ages that range from circa $2090 \pm 17 \mathrm{Ma}$ to $1215 \pm 20 \mathrm{Ma}$, with the younger group of zircons considered as a maximum sedimentation age for the sequence [Rizzotto et al., 1999]. Deformed leucocratic melts injected along bedding planes from the same locality yield an age of $1122 \pm 12 \mathrm{Ma}$, possibly constraining the timing of meta- morphism [Santos et al., 2000]. Two episodes of felsic intrusions characterize much of the NBMB (Figure 2a). The first set of intrusions, the Rio Branco suite, yields a conventional U-Pb zircon age of $1098 \pm 10 \mathrm{Ma}$, with cogenetic gabbros yielding a U-Pb zircon age of $1110 \pm$ $15 \mathrm{Ma}$ [Rizzotto et al., 1999]. Both of these ages are in agreement with U-Pb SHRIMP ages of $1113 \pm 56 \mathrm{Ma}$ measured from a zircon of the Rio Branco granite [Santos et al., 2000]. The Rio Branco suite was emplaced syntectonically and is characterized by a gneissic foliation with locally developed mylonitic fabrics. The second intrusive suite, known as the Rio Pardo Granite, yields $\mathrm{U} / \mathrm{Pb}$ ages of 
a)

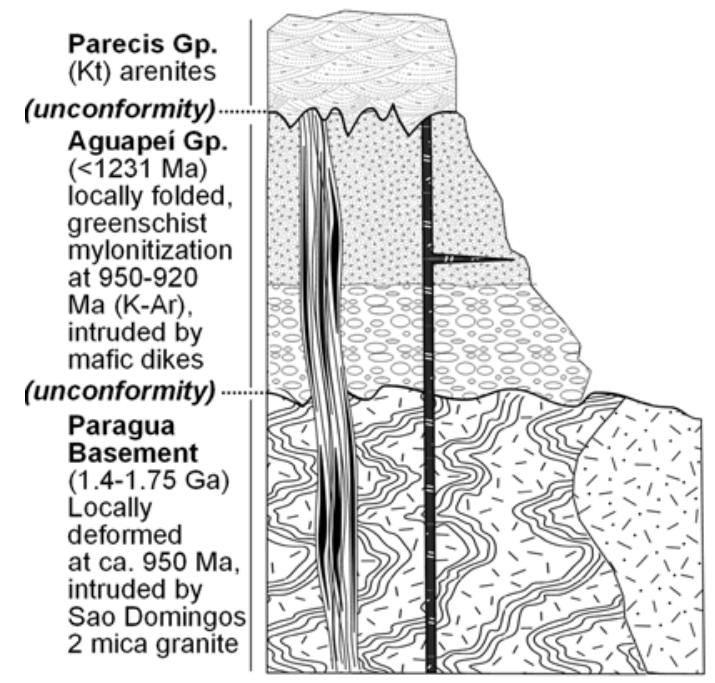

b)

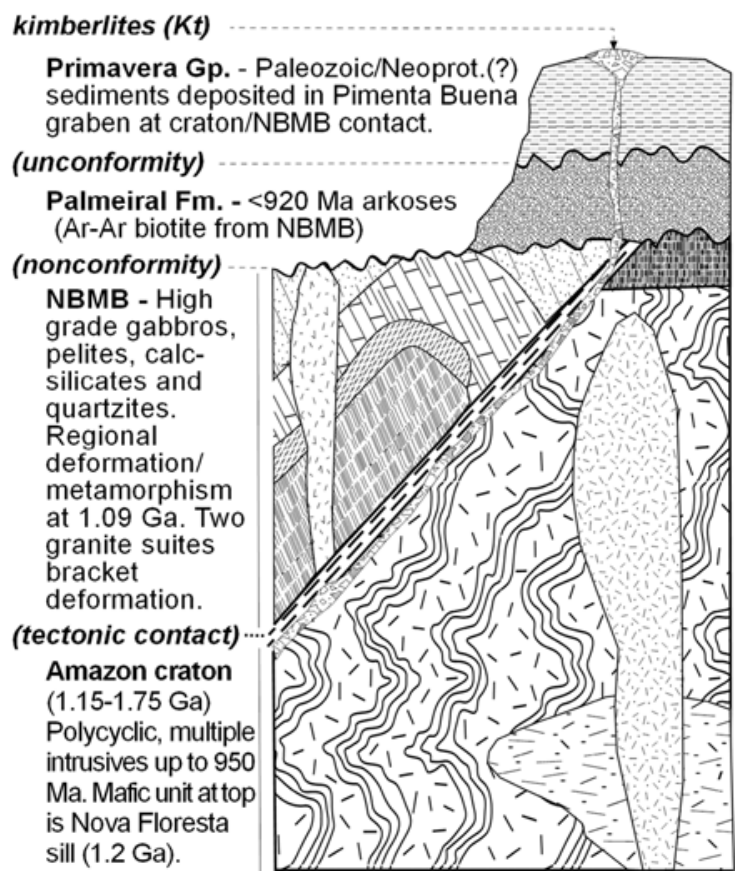

Figure 2. Schematic diagram of the tectonostratigraphic framework of the (a) southern boundary of the Amazon craton together with the adjacent Nova Brasilândia belt and (b) interior of the Paragua craton in the region of the Aguapeí belt in the SE portion of Figure 1.

$1005 \pm 41 \mathrm{Ma}$ [Rizzotto et al., 1999] and a Rb-Sr isochron age of $1003 \pm 22 \mathrm{Ma}\left({ }^{87} \mathrm{Sr} /{ }^{86} \mathrm{Sr}_{0}=0.7038, \mathrm{MSWD}=0.3\right.$ (C. C. G. Tassinari, Resultados radiométricos pelos métodos $\mathrm{Rb}-\mathrm{Sr}$ e K-Ar de rochas do sudoestede Rondônia, internal report, Co. de Pesquisa de Recursos Minerais, São Paolo), which are interpreted as a crystallization age. The majority of these granites display synkinematic to late kinematic emplacement fabrics, with a small subset intruded at high crustal levels after the cessation of deformation, as evidenced by the preservation of miarolitic cavities (Figure 2b).

[7] The Amazon craton basement lies to the north of the NBMB and is best exposed in the central portion of the Brazilian state of Rondônia. The polydeformed basement is marked by the development of a large network of strike-slip, mylonitic shear zones that display a systematic sinistral shear sense, postulated to be the result of early collision of the Amazon craton with southernmost Laurentia. This network of shear zones was active after $\sim 1.2$ Ga under midamphibolite facies conditions and is observed to overprint both igneous and preexisting metamorphic rock fabrics. The late Mesoproterozoic deformation is the final episode in a complex history of metamorphism and multiple intrusions that range in age from circa $1.75 \mathrm{Ga}$ to $1.15 \mathrm{Ga}$ [Bettencourt et al., 1996; Payolla et al., 2002]. The last magmatic episode that affected this portion of the Amazon craton was the emplacement of the tin-bearing Younger Granites of Rondônia at circa $970 \mathrm{Ma}$ [Bettencourt et al., 1999].
The intrusion of these granites at hypabyssal depths and their presently undeformed state may mark the final stages of cratonization in this area.

[8] The actual boundary between the Amazon craton and the NBMB is covered by three, flat-lying sequences of continental sediments, attesting to at least three episodes of reactivation (Figure 1). The Palmeiral Formation is the oldest stratigraphic unit and comprises pinkish arkosic sandstones and quartzitic conglomerates with decimeter to meter scale cross beds [Leal et al., 1978]. Imbricated structures indicate southward directed paleocurrents for the deposition of these continental arkoses, the immaturity of which suggests proximal sources [Bahia, 1997]. The Palmeiral Formation unconformably overlies the $1198 \pm$ 3 Ma gabbroic sill and subaerial basalts of the Nova Floresta Formation [Leal et al., 1978; Tohver et al., 2002]. The contact of the Palmeiral Formation with the metasediments of the NBMB is an angular nonconformity, suggesting that deposition postdates the uplift and cooling of the NBMB [Scandolara and Rizzotto, 1998]. A second episode of reactivation is marked by deposition of the Primavera Group into the Pimenta Bueno graben during the Paleozoic (late Neoproterozoic?). The sediments of this Primavera Group comprise arenites, glaciogenic diamictites, ferruginous sandstones, and dolomites that reflect a shallow marine environment [Leal et al., 1978; Scandolara et al., 1999]. A final episode of reactivation is marked by late Jurassic volcanism throughout the region including the emplacement of kimberlites and alkaline basalts [Montes-Lauar et al., 


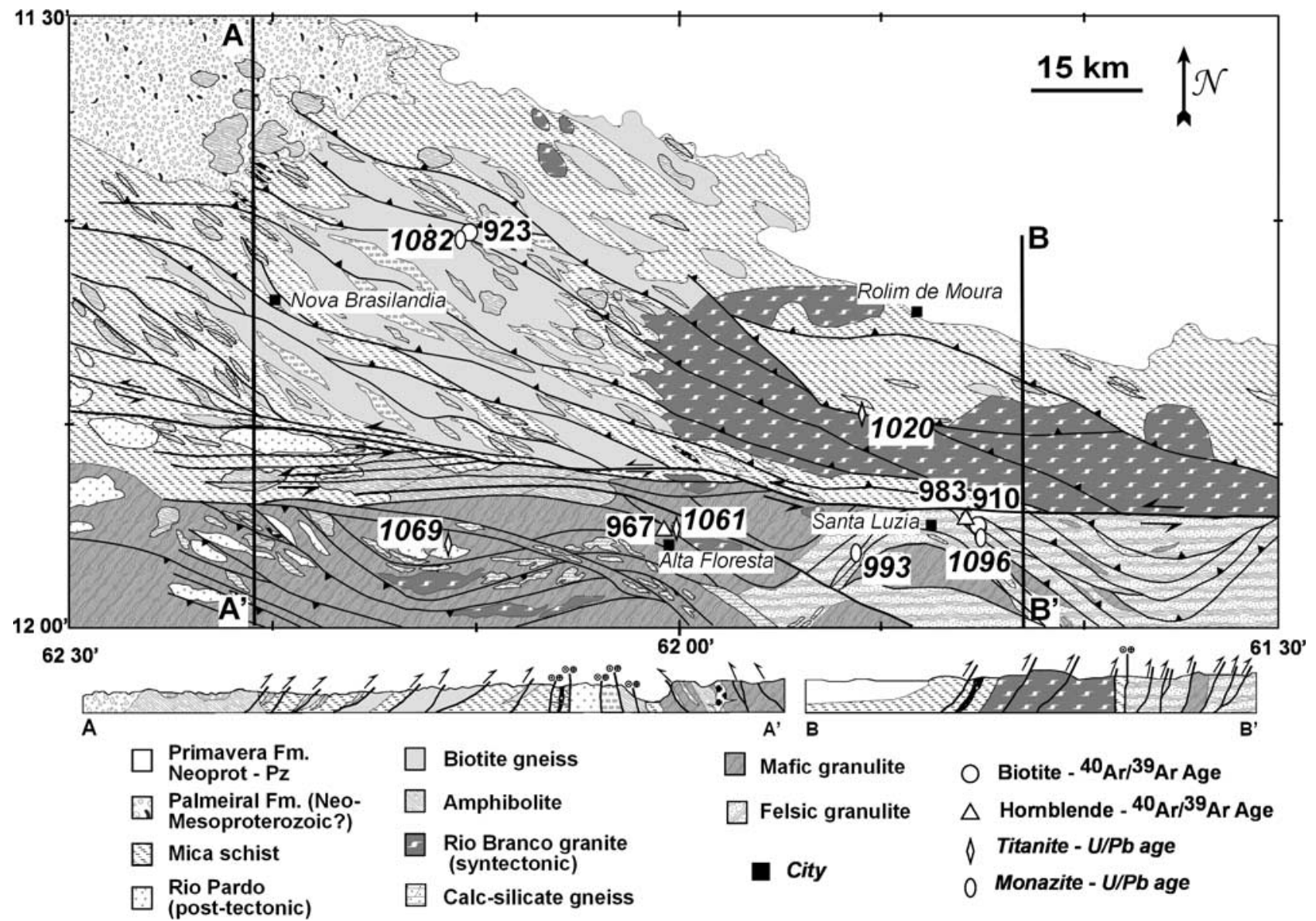

Figure 3. Map of portion of Nova Brasilândia belt compiled from regional maps (Rio Pardo and Paulo Saldanha 1:100,000 quadrangles by Bahia and Silva [1998] and Scandolara and Rizzotto [1998]. Schematic cross sections indicate a regional structure with double vergence. Strike-slip mylonite zones with sinistral offset predominate in the central domain. Age data from $\mathrm{U} / \mathrm{Pb}$ and ${ }^{40} \mathrm{Ar} /{ }^{39} \mathrm{Ar}$ analysis from this study are shown, indicating regional cooling after circa $1.05 \mathrm{Ga}$.

1994]. Continental sedimentation (Parecis Formation) of early Cretaceous age followed this volcanism.

\section{Structure}

[9] Regional mapping and metallogenic prospecting of the Nova Brasilândia Metasedimentary belt was carried out systematically by the Brazilian Geological Service (CPRM) at the $1: 100,000$ scale in the $7200 \mathrm{~km}^{2}$ region centered between the towns of Nova Brasilândia d'Oeste and Rolim de Moura [Scandolara and Rizzotto, 1998; Bahia and Silva, 1998] compiled in Figure 3. Foliations in the NBMB are defined by the development of both mylonitic shear zones and metamorphic fabric, generated by mineral growth and transposition of sedimentary fabrics. Mylonitic foliations are observed to be both concordant and in a crosscutting relationship to metamorphic fabrics, suggesting a sequential history of development discussed below. The metamorphic fabrics range in intensity from a well-developed schistosity typical of metapelitic units, to the development of banded gneisses, which generally characterize calc-silicate units and higher-grade pelitic rocks. Massive textures characterize some calc-silicate units as well as the majority of metabasites, with amphibole typically overgrowing a relict cumulate texture. Lineations are defined by the presence of a preferred mineral orientation, generally formed by quartz ribbons, deformed feldspar augens, or the alignment of acicular mineral grains [Luft et al., 2000].

[10] A NNE dipping fabric is commonly observed throughout the northern portion of the mapped region, characterizing both the attitude of mylonitic shear zones and regional rock fabrics. Regional strike for these rocks varies from $\mathrm{N} 60^{\circ} \mathrm{W}$ to approximately E-W. Fabrics with the opposite vergence are observed locally in the southern domain, with more dispersion in regional strike, varying from $\mathrm{N} 60^{\circ} \mathrm{E}$ to $\mathrm{N} 60^{\circ} \mathrm{W}$. Lineations from these two domains are characterized by intermediate to high rake angles, suggestive of a major component of dip-slip motion and secondary component of strike-slip motion. On a regionalscale cross section of the western portion of the mapped region, the NBMB displays a doubly verging structure, with 

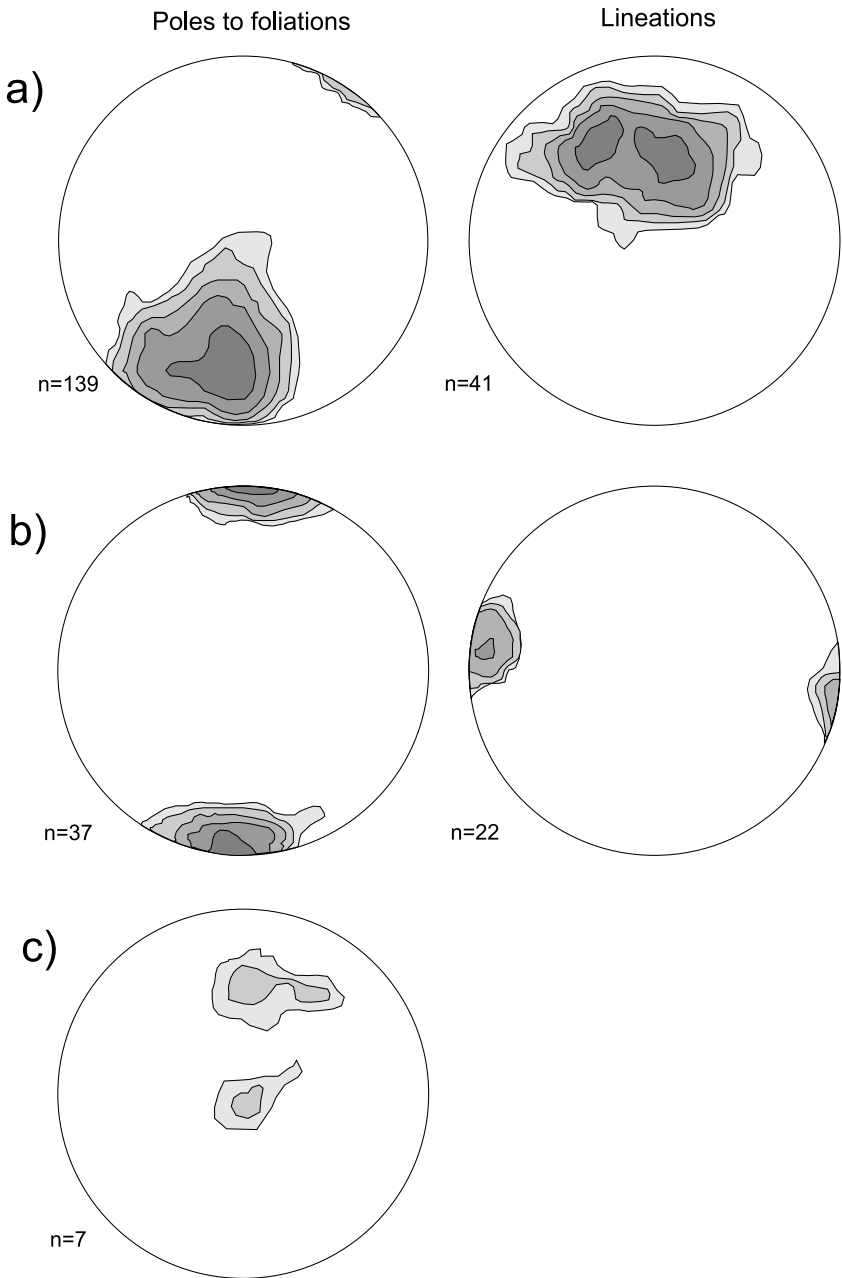

Figure 4. Lower hemisphere stereonet projections of poles to foliation and lineations compiled from the Rio Pardo and Paulo Saldanha quadrangle sheets with contours at 1, 2, 4, 8 , and $16 \%$ for the (a) northern, (b) central, and (c) southern domains [Bahia and Silva, 1998; Scandolara and Rizzotto, 1998]. The average foliation pattern in the northern domain (Figure 4a) is NE dipping, although a small population from the southern domain displays the opposite vergence, observed as an isolated population in Figure 4c. Lineations observed in the northern domain (Figure 4a) are consistent with dip-slip transport. In the central domain (Figure 4b) shallow rake lineations are associated with steeply dipping rock foliations, suggesting strike-slip tectonic transport.

the average fabric inclined toward the juncture between the two domains. Vertical fabrics are observed in the boundary zone with lineations that define a girdle about the horizontal plane, suggestive of predominantly strike-slip motion (Figure 4).

[11] Two deformational phases characterize the structural evolution of the NBMB, with an initial NE directed compressional event marked by the pervasive development of the NW trending fabrics [Bahia and Silva, 1998; Scandolara and Rizzotto, 1998]. Thrust faulting was active during this phase with tectonic transport to the southwest. This deformational event seems to have been progressively followed by the development of E-W trending sinistral, strike-slip mylonitic zones, since there is not a clear difference in the metamorphic conditions at which these events occurred [Luft et al., 2000]. The second deformational phase was marked by the intrusion of the juvenile rocks of the Rio Pardo granite suite, which shows a strong protomylonitic to mylonitic foliation, generally striking E-W with anastamosing portions striking WNW. The strike-slip motion is consistent with large-scale sinistral offsets observed in the Sunsás belt [Litherland et al., 1986]. Thus it is concluded that both the NBMB and Sunsás belt were involved in an orogenic zone characterized by large-scale sinistral strike-slip motion at circa $1.05 \mathrm{Ga}$ [Litherland et al., 1986, 1989].

\section{Metamorphic Petrology}

[12] The NBMB is characterized by an increase in metamorphic grade from north to south. The northern portion of the sampled region consists largely of impure quartzites and micaceous, sillimanite-bearing schists, the more micaceous of which have undergone extensive weathering. The $\mathrm{S}_{0}$ planes been affected by at least two generations of folding, as well as the injection of melt along bedding planes (Figure 5b). Zircons from this anatectic melt, which is interpreted to be locally derived, yield a U/Pb age of $1100 \pm 8 \mathrm{Ma}$ [Rizzotto et al., 1999]. Most of the mica schist samples are sillimanite-bearing, but one sample contains the assemblage $\mathrm{Ky}+\mathrm{St}+\mathrm{Sil}+$ $\mathrm{Ms}+\mathrm{Bio}+\mathrm{Qz}+\mathrm{Plag}+\mathrm{Ru}$ with the sillimanite appearing as a late phase growing in biotite (Figure 6a). Calc-silicate rocks are rare in the northern domain, restricted to small lenses and tremolite-rich quartzites. Lenses of amphibolite in the region are of massive aspect, with some evidence of a relict igneous layering. A typical mineral assemblage found in the amphibolites is Plag $+\mathrm{Hb}+\mathrm{Ilm}+\mathrm{Mag} \pm$ $\mathrm{Cm} \pm$ Trm with retrograde chlorite appearing in some samples (Table 1).

[13] The presence of one- and two-pyroxene granulite facies rocks occurs only in the southern domain of the studied region. Calc-silicate rocks are more common than in the north, appearing as both banded gneisses with alternating greenish black and pink layers consisting $\mathrm{Qz}+$ $\mathrm{Plag}+\mathrm{Sph} \pm \mathrm{Scap}+\mathrm{Di}$ interlayered with $\mathrm{Hb}+\mathrm{Plag}+\mathrm{Qz}$. Some spectacular examples of these calc-silicate banded gneiss consist almost entirely of Plag $+\mathrm{Gar}+\mathrm{Qz}+\mathrm{Di}+$ Sph. Pelitic rocks in the southern domain are characterized by a gneissic foliation, defined by the alignment of mica grains. In the highest-grade assemblages, south of the town of Santa Luzia, mylonitization has imparted a lineation partially formed by elongate garnet grains with abundant sillimanite as both inclusions and in the matrix. Fluorineand Ti-rich biotite is found as a stable phase in some high-grade rocks in the southern portion of the NBMB (Figure 6b), but biotite is generally absent in pyroxenebearing rocks of the granulite facies from this southern domain (Figure 6c). 


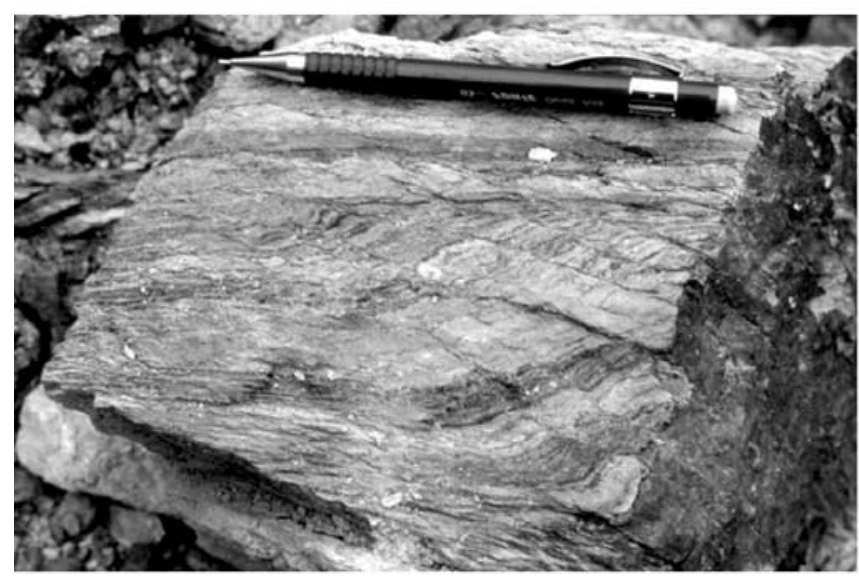

a)

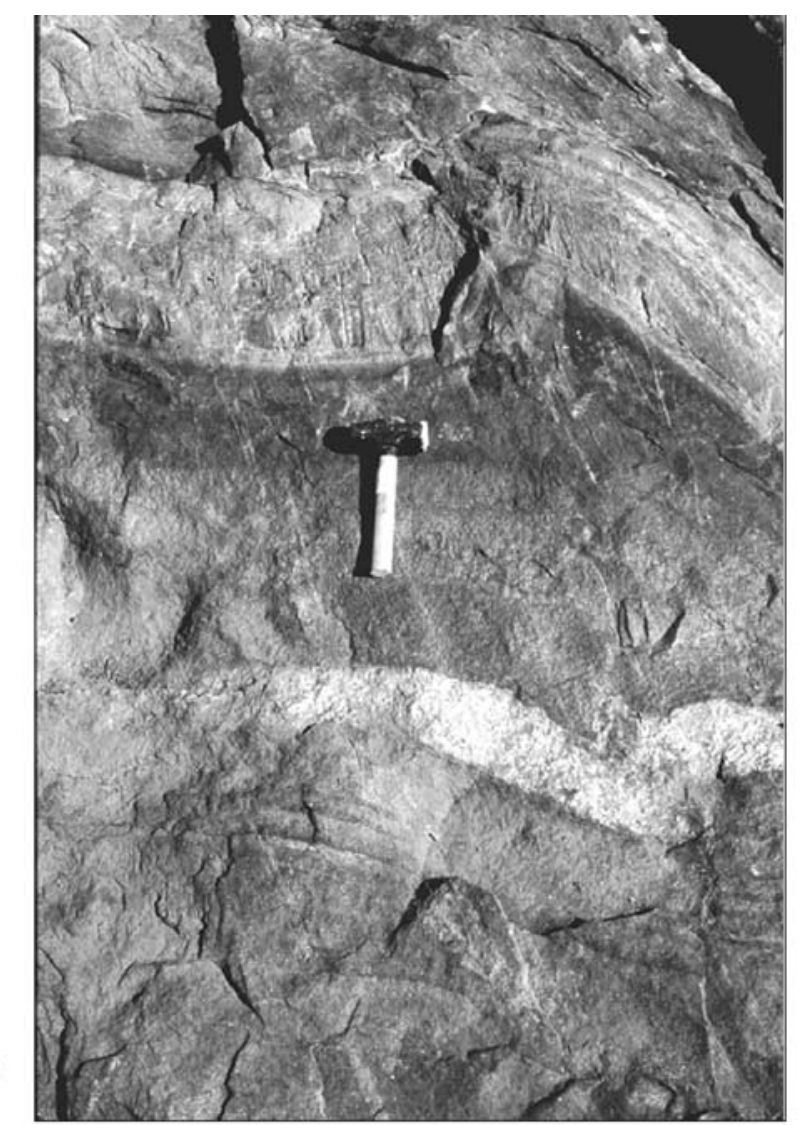

Figure 5. (a) View of typical deformation features in the Aguapeí belt registering dynamic metamorphism under greenschist facies; (b) deformation of the Nova Brasilândia belt accompanied by partial melting (leucosomatic dike in middle of photograph). In spite of the sillimanite-grade metamorphism, the turbiditic features of the Nova Brasilândia protolith are well preserved, as evidenced by the repetitive stratigraphy in the lower portion of the photograph.

[14] Samples were selected for calculations of pressure and temperature on the basis of mineral assemblages. Electron microprobe analysis was undertaken using a Cameca SX-100 with analyses obtained by comparison with natural silicate and oxide mineral standards from the collection of the University of Michigan Electron Microanalysis Laboratory. The loci of independent reactions were calculated using the internally consistent thermodynamic database of Thermocalc v.3.1. Activity coefficients were determined for various solid solutions in pyroxene, plagioclase feldspar, biotite, and hornblende using the A-X program of Holland and Powell [1998]. The activity of garnet species was calculated with the asymmetric Quaternary mixing model of Ganguly et al. [1996]. Representative mineral analyses used for thermobarometric calculations are contained in Tables 2-6. Sample 326 is a pelitic schist from the northern portion of the NBMB with the assemblage $\mathrm{Ky}+\mathrm{St}+\mathrm{Sil}+\mathrm{Bi}+\mathrm{Ms}+\mathrm{Kfs}+$ Plag + Qz. Kyanite, staurolite, and muscovite appear as relict grains overprinted by a fine-grained matrix of sillimanite, K-feldspar, and biotite (Figure 6a). The presence of muscovite places an additional constraint on metamorphic conditions, which can be described by three independent reactions:

1) $\mathrm{Al}_{2} \mathrm{SiO}_{5} \leftrightarrow \mathrm{Al}_{2} \mathrm{SiO}_{5}$ kyanite $\leftrightarrow$ sillimanite

2) $6 \mathrm{Fe}_{4} \mathrm{Al}_{18} \mathrm{Si}_{7.5} \mathrm{O}_{46}(\mathrm{OH})_{2}+8 \mathrm{KAl}_{3} \mathrm{Si}_{3} \mathrm{O}_{10}(\mathrm{OH})_{2}+17$ $\mathrm{SiO}_{2} \leftrightarrow 8 \mathrm{KFe}_{3} \mathrm{Si}_{3} \mathrm{AlO}_{10}(\mathrm{OH})_{2}+62 \mathrm{Al}_{2} \mathrm{SiO}_{5}+12$ $\mathrm{H}_{2} \mathrm{O}$

Fe-staurolite + muscovite + quartz $\leftrightarrow$ Fe-biotite + aluminosilicate + water

3) $\mathrm{KAl}_{3} \mathrm{Si}_{3} \mathrm{O}_{10}(\mathrm{OH})_{2}+\mathrm{SiO}_{2} \leftrightarrow \mathrm{KAlSi}_{3} \mathrm{O}_{8}+\mathrm{Al}_{2} \mathrm{SiO}_{5}+$ $\mathrm{H}_{2} \mathrm{O}$

muscovite + quartz $\leftrightarrow$ K-feldspar + aluminosilicate + water

The locus of the staurolite breakdown reaction, corrected for solid solution, is below the terminal reaction, Fe-staurolite + quartz $\leftrightarrow$ garnet + biotite + sillimanite $+\mathrm{H}_{2} \mathrm{O}$, which may account for the lack of garnet in the rock. Another possible explanation for the absence of garnet is the highly magnesian 

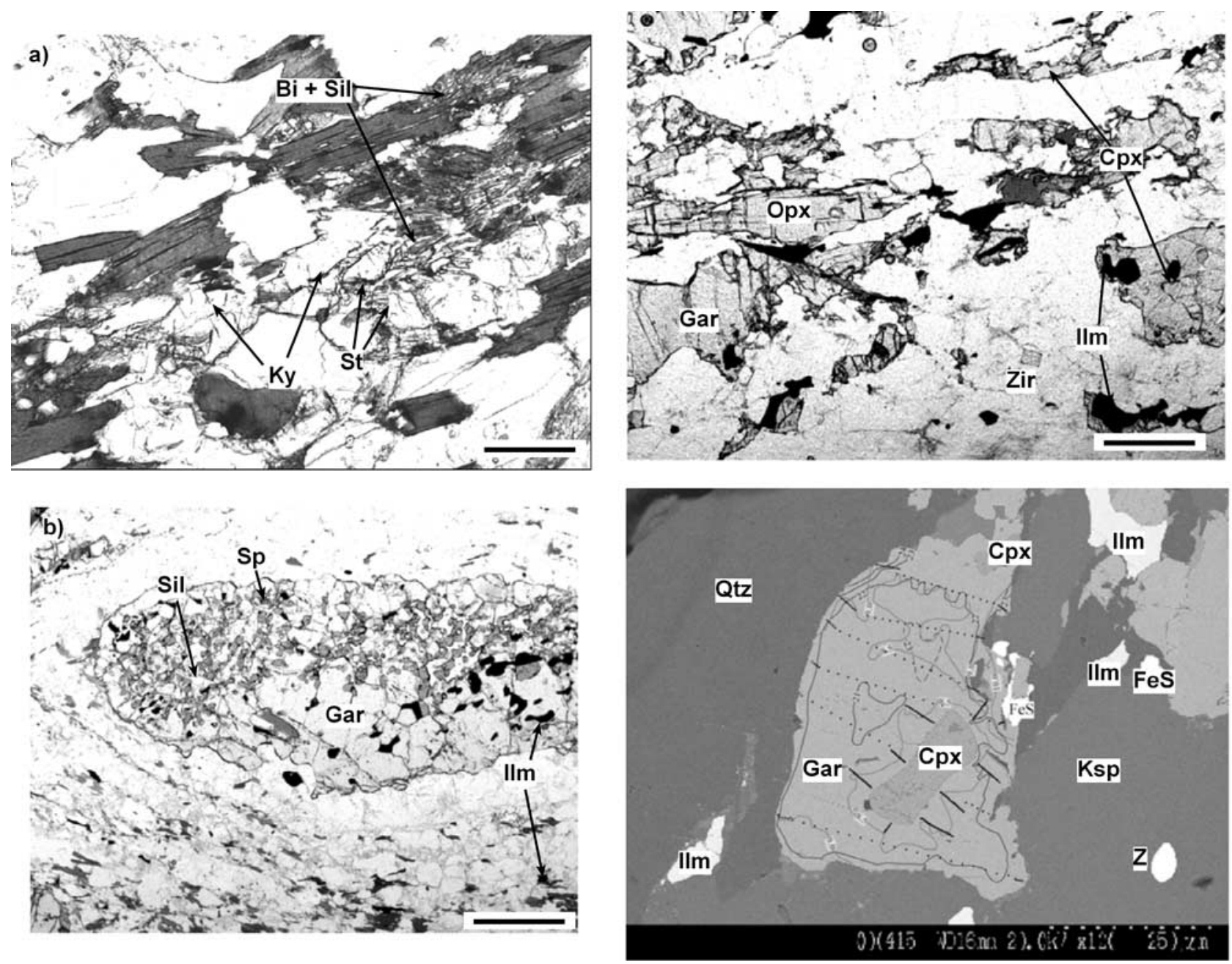

Figure 6. (a) Typical pelitic assemblage (sample 326) from the low-grade, northern portion of the Nova Brasilândia belt. Observe the relict staurolite and kyanite overprinted by a fine-grained mesh of sillimanite and biotite. (b) High-grade pelitic assemblage (sample 134) from the southern portion of the belt with mylonitic foliation. Gray inclusions in elongate garnet are spinel, with both sillimanite and ilmenite found as inclusions and in the matrix. Rutile is found only as a matrix phase. (c) Two-pyroxene garnet granulite (sample 327.1) with clinopyroxene inclusion in garnet. (d) Example of retrograde $\mathrm{Mg}-\mathrm{Fe}$ halo surrounding clinopyroxene inclusion in garnet. Black lines are grossular contours (20-24 mol\%), while Mg\# contours are drawn at 0.5 intervals (gray lines). Note the difference in $\mathrm{Mg \#}$ for the garnet grain close to matrix pyroxene and garnet profile in Figure 8, taken from a garnet removed from other ferromagnesian phases. Scale bar is $1 \mathrm{~mm}$ for all samples, except for Figure 6d, where scale bar is $100 \mu \mathrm{m}$.

bulk composition of the rock, as indicated by an $\mathrm{Mg \#}$ of 50 for biotite, the modally dominant ferromagnesian phase (cf. Figure 1 of Thompson [1976]). The coexistence of kyanite and staurolite indicates early equilibrium under high P-T conditions. The breakdown of staurolite suggests an increase in temperature from this early equilibrium state, given the steep $\mathrm{dP} / \mathrm{dT}$ that characterizes reaction 2 in the kyanite field,. The breakdown of kyanite is more likely the result of a decrease in pressure, because further increases in temperature would have resulted in the growth of garnet (Figure 7, arrow 1). The presence of a melt phase in numerous outcrops in the region suggests that the $\mathrm{H}_{2} \mathrm{O}$-saturated solidus for haplogranite may have been exceeded locally (Figure 7).
[15] Two samples from the southern domain were used to constrain the P-T conditions of the high-grade portion of the NBMB. Sample 327.1 is a two-pyroxene garnet granulite with the assemblage Kfs + Plag + Qz + Gar + Opx + Cpx + $\mathrm{Ilm}+\mathrm{Ap}+\mathrm{Zc}$. Hornblende is observed as overgrowths on pyroxene, and so is not considered to be part of the peak assemblage. Garnets are subhedral to euhedral, with compositional profiles characterized by an increase ( $\sim 4 \mathrm{~mol} \%)$ in grossular content toward the rims $(\sim 50 \mu \mathrm{m}$ thick $)$, but little change in $\mathrm{Mg \#}$. However, $\mathrm{Mg \#}$ does vary from one garnet grain to another, with the highest values preserved in grains distant from other ferromagnesian phases, possibly reflecting a lack of resetting upon cooling. Inclusions in garnet include clinopyroxene, orthopyroxene, plagioclase 
Table 1. Representative Mineral Assemblages ${ }^{\mathrm{a}}$

\begin{tabular}{|c|c|c|c|c|c|c|c|c|c|c|c|c|c|c|c|c|c|c|}
\hline Sample & Description & Gar & $\mathrm{Bi}$ & Als & Ms & Qz & Plag & $\mathrm{Kfs}$ & $\mathrm{Hb}$ & Amp & St & Chl & $\mathrm{Ru}$ & $\mathrm{Ilm}$ & Sph & Opx & Cpx & Other \\
\hline ron127 & mica schist & $\ldots$ & $\mathrm{x}$ & $\ldots$ & $\mathrm{x}$ & $\mathrm{x}$ & $\mathrm{x}$ & $\ldots$ & $\cdots$ & & $\ldots$ & $\ldots$ & $\ldots$ & $\mathrm{x}$ & $\ldots$ & $\ldots$ & $\ldots$ & $\ldots$ \\
\hline ron 128 & amphibolite & $\ldots$ & $\ldots$ & $\ldots$ & $\ldots$ & $\ldots$ & $\mathrm{x}$ & $\ldots$ & $\mathrm{x}$ & $\mathrm{Cm}$ & $\ldots$ & $\ldots$ & $\ldots$ & $\mathrm{x}$ & $\ldots$ & $\ldots$ & $\ldots$ & $\ldots$ \\
\hline ron 130 & amphibolite & $\ldots$ & $\mathrm{x}$ & $\ldots$ & $\ldots$ & $\ldots$ & $\mathrm{x}$ & $\ldots$ & $\mathrm{x}$ & $\ldots$ & $\ldots$ & $\mathrm{r}$ & $\ldots$ & $\mathrm{x}$ & $\ldots$ & $\ldots$ & $\ldots$ & $\ldots$ \\
\hline ron 131 & metabasite & $\ldots$ & $\mathrm{x}$ & $\ldots$ & $\ldots$ & $\ldots$ & $\mathrm{x}$ & $\ldots$ & $\mathrm{x}$ & Trm & $\ldots$ & $\mathrm{x}$ & $\ldots$ & $\mathrm{x}$ & $\ldots$ & $\ldots$ & $\ldots$ & $\mathrm{mt}$ \\
\hline ron 132 & calc-silicate & $\ldots$ & $\ldots$ & $\ldots$ & $\ldots$ & $\ldots$ & $\ldots$ & $\ldots$ & $\ldots$ & $\ldots$ & $\ldots$ & $\ldots$ & $\ldots$ & $\ldots$ & $\ldots$ & $\ldots$ & $\ldots$ & scp \\
\hline ron 133 & metabasite & $\ldots$ & $\ldots$ & $\ldots$ & $\ldots$ & $\mathrm{x}$ & $\mathrm{x}$ & $\ldots$ & $\mathrm{x}$ & $\ldots$ & $\ldots$ & $\ldots$ & $\ldots$ & $\ldots$ & $\ldots$ & $\mathrm{x}$ & $\mathrm{x}$ & $\ldots$ \\
\hline ron 134 & mylonitic gneiss & $\mathrm{x}$ & $\mathrm{x}$ & Sil & $\mathrm{x}$ & $\mathrm{x}$ & $\mathrm{x}$ & $\mathrm{x}$ & $\ldots$ & $\ldots$ & $\ldots$ & $\ldots$ & $\mathrm{x}$ & $\mathrm{x}$ & $\ldots$ & $\ldots$ & $\ldots$ & Mon, Zc, Gr \\
\hline ron $135 b$ & amphibolite & $\ldots$ & $\ldots$ & $\ldots$ & $\ldots$ & & $\mathrm{x}$ & $\ldots$ & $\mathrm{x}$ & $\ldots$ & $\ldots$ & $\ldots$ & $\ldots$ & $\mathrm{x}$ & $\mathrm{x}$ & $\ldots$ & $\ldots$ & $\ldots$ \\
\hline ron $135 a$ & calc-silicate & $\ldots$ & $\ldots$ & $\ldots$ & $\ldots$ & $\mathrm{x}$ & $\mathrm{x}$ & $\ldots$ & $\mathrm{x}$ & $\ldots$ & $\ldots$ & $\ldots$ & $\ldots$ & $\ldots$ & $\mathrm{x}$ & $\ldots$ & $\ldots$ & Scap \\
\hline ron 137 & granitoid & $\ldots$ & $\mathrm{x}$ & $\ldots$ & $\ldots$ & $\mathrm{x}$ & $\mathrm{x}$ & $\mathrm{x}$ & $\ldots$ & $\ldots$ & $\ldots$ & $\ldots$ & $\ldots$ & $\mathrm{x}$ & $\ldots$ & $\ldots$ & $\ldots$ & $\mathrm{Zc}$ \\
\hline ron 138 & mica schist & $\ldots$ & $\ldots$ & $\ldots$ & $\mathrm{x}$ & $\mathrm{x}$ & $\mathrm{x}$ & $\mathrm{x}$ & $\ldots$ & $\ldots$ & $\ldots$ & $\ldots$ & $\ldots$ & $\ldots$ & $\ldots$ & $\ldots$ & $\ldots$ & Mon \\
\hline ron 139 & mica schist & $\ldots$ & $\mathrm{x}$ & $\ldots$ & $\ldots$ & $\mathrm{x}$ & $\mathrm{x}$ & $\ldots$ & $\ldots$ & $\ldots$ & $\ldots$ & $\ldots$ & $\mathrm{x}$ & $\mathrm{x}$ & $\ldots$ & $\ldots$ & $\ldots$ & $\ldots$ \\
\hline Ron 316 & calc-silicate & $\ldots$ & $\ldots$ & $\ldots$ & $\ldots$ & $\mathrm{x}$ & $\mathrm{x}$ & $\ldots$ & $\ldots$ & $\ldots$ & $\ldots$ & $\ldots$ & $\ldots$ & $\ldots$ & $\mathrm{x}$ & $\ldots$ & $\mathrm{x}$ & Scp \\
\hline ron 317 & granitoid & $\ldots$ & $\mathrm{x}$ & $\ldots$ & $\mathrm{x}$ & $\mathrm{x}$ & $\mathrm{x}$ & $\mathrm{x}$ & $\ldots$ & $\ldots$ & $\ldots$ & $\ldots$ & $\ldots$ & $\mathrm{x}$ & $\ldots$ & $\ldots$ & $\ldots$ & All \\
\hline ron 319 & calc-silicate & $\ldots$ & $\ldots$ & $\ldots$ & $\ldots$ & $\mathrm{x}$ & $\mathrm{x}$ & $\ldots$ & $\ldots$ & Trm & $\ldots$ & $\ldots$ & $\ldots$ & $\ldots$ & $\mathrm{x}$ & $\ldots$ & $\mathrm{x}$ & $\ldots$ \\
\hline ron 320 & amphibolite & $\ldots$ & $\mathrm{x}$ & $\ldots$ & $\mathrm{x}$ & $\mathrm{x}$ & $\mathrm{x}$ & $\ldots$ & $\ldots$ & $\ldots$ & $\ldots$ & $\ldots$ & $\mathrm{x}$ & $\mathrm{x}$ & $\ldots$ & $\ldots$ & $\ldots$ & $\ldots$ \\
\hline ron 322.2 & calc-silicate & $\ldots$ & $\ldots$ & $\ldots$ & $\ldots$ & $\mathrm{x}$ & $\mathrm{x}$ & $\ldots$ & $\mathrm{x}$ & $\ldots$ & $\ldots$ & $\ldots$ & $\ldots$ & $\ldots$ & $\ldots$ & $\ldots$ & $\mathrm{x}$ & $\ldots$ \\
\hline ron 324d & mica schist & $\ldots$ & $\mathrm{x}$ & Sil & $\mathrm{x}$ & $\mathrm{x}$ & $\mathrm{x}$ & $\ldots$ & $\ldots$ & $\ldots$ & $\mathrm{x}$ & $\ldots$ & $\mathrm{x}$ & $\ldots$ & $\ldots$ & $\ldots$ & $\ldots$ & Mon,Zc \\
\hline Ron 325 & mica schist & $\ldots$ & $\mathrm{x}$ & Sil & $\mathrm{x}$ & $\mathrm{x}$ & $\mathrm{x}$ & $\ldots$ & $\ldots$ & $\ldots$ & $\ldots$ & $\mathrm{r}$ & $\ldots$ & $\mathrm{x}$ & $\ldots$ & $\ldots$ & $\ldots$ & Mon,Zc \\
\hline ron 326 & mica schist & $\ldots$ & $\mathrm{x}$ & Ky, Sil & $\mathrm{x}$ & $\mathrm{x}$ & $\mathrm{x}$ & $\ldots$ & $\ldots$ & $\ldots$ & $\mathrm{x}$ & $\ldots$ & $\ldots$ & $\ldots$ & $\ldots$ & $\ldots$ & $\ldots$ & Mon \\
\hline ron 327.1 & garnet granulite & $\mathrm{x}$ & $\ldots$ & $\ldots$ & $\ldots$ & $\mathrm{x}$ & $\mathrm{x}$ & $\mathrm{x}$ & $\ldots$ & $\ldots$ & $\ldots$ & $\ldots$ & $\ldots$ & $\mathrm{x}$ & $\ldots$ & $\mathrm{x}$ & $\mathrm{x}$ & $\mathrm{Zc}, \mathrm{FeS}$ \\
\hline ron 328 & amphibolite & $\ldots$ & $\ldots$ & $\ldots$ & $\ldots$ & $\mathrm{x}$ & $\mathrm{x}$ & $\ldots$ & $\mathrm{x}$ & $\ldots$ & $\ldots$ & $\mathrm{r}$ & $\ldots$ & $\mathrm{x}$ & $\mathrm{x}$ & $\ldots$ & $\ldots$ & $\ldots$ \\
\hline Ron 329 & granulite & $\ldots$ & $\ldots$ & $\ldots$ & $\ldots$ & $\mathrm{x}$ & $\mathrm{x}$ & $\mathrm{x}$ & $\ldots$ & $\ldots$ & $\ldots$ & $\ldots$ & $\ldots$ & $\ldots$ & $\ldots$ & $\mathrm{x}$ & $\mathrm{x}$ & $\mathrm{Zc}$ \\
\hline Ron 401b & mica schist & $\ldots$ & $\mathrm{x}$ & $\ldots$ & $\mathrm{x}$ & $\mathrm{x}$ & $\mathrm{x}$ & $\ldots$ & $\ldots$ & $\ldots$ & $\ldots$ & $\ldots$ & $\ldots$ & $\ldots$ & $\ldots$ & $\ldots$ & $\ldots$ & $\mathrm{Zc}$ \\
\hline Ron $404 \mathrm{c}$ & mica schist & $\ldots$ & $\mathrm{x}$ & $\ldots$ & $\mathrm{x}$ & $\mathrm{x}$ & $\mathrm{x}$ & $\ldots$ & $\ldots$ & $\ldots$ & $\ldots$ & $\ldots$ & $\ldots$ & $\mathrm{x}$ & $\ldots$ & $\ldots$ & $\ldots$ & Mon \\
\hline Ron 404d & mica schist & $\ldots$ & $\ldots$ & $\ldots$ & $\ldots$ & $\mathrm{x}$ & $X$ & $\ldots$ & $\ldots$ & Grn & $\ldots$ & $\ldots$ & $\ldots$ & $\ldots$ & $\mathrm{x}$ & $\ldots$ & $\ldots$ & $\mathrm{Zc}$ \\
\hline Ron 404f & mica schist & $\ldots$ & $\mathrm{x}$ & Sil & $\mathrm{x}$ & $\mathrm{x}$ & $X$ & $\ldots$ & $\ldots$ & $\ldots$ & $\ldots$ & $\ldots$ & $\mathrm{x}$ & $\mathrm{x}$ & $\mathrm{x}$ & $\ldots$ & $\ldots$ & $\mathrm{Zc}$ \\
\hline
\end{tabular}

${ }^{a}$ Abbreviations are as follows: Gar, garnet; Bi, biotite; Als, aluminosilicate; Ms, muscovite; Qz, quartz; Plag, plagioclase; Kfs, K-feldspar; Hb, hornblende; Amp, other amphiboles; St, staurolite; Chl, chlorite; Ru, rutile; Ilm, ilmenite; Sph, titanite; Opx, orthopyroxene; Cpx, clinopyroxene; Sil, sillimanite; Ky, kyanite; Mic, microcline; Cm, cummingtonite; Trm, tremolite; Grn, grunerite; Mag, magnetite; Scp, scapolite; Gr, graphite; All, allanite; Mon, monazite; Zc, zircon; r, retrograde.

Table 2. Pyroxene Analyses ${ }^{\mathrm{a}}$

\begin{tabular}{|c|c|c|c|c|}
\hline Sample & $\begin{array}{l}327 \text { Opx } \\
\text { Matrix }\end{array}$ & $\begin{array}{l}327 \mathrm{Cpx} \\
\text { Matrix }^{\mathrm{b}}\end{array}$ & $\begin{array}{l}327 \text { Opx } \\
\text { Inclusion }^{\mathrm{b}}\end{array}$ & $\begin{array}{l}327 \mathrm{Cpx} \\
\text { Inclusion }^{\mathrm{b}}\end{array}$ \\
\hline $\mathrm{SiO}_{2}$ & 48.74 & 50.74 & 48.45 & 50.48 \\
\hline $\mathrm{TiO}_{2}$ & 0.02 & 0.01 & 0.01 & 0.01 \\
\hline $\mathrm{Al}_{2} \mathrm{O}_{3}$ & 0.16 & 1.02 & 0.53 & 1.19 \\
\hline $\mathrm{Cr}_{2} \mathrm{O}_{3}$ & 0.06 & 0.01 & 0.00 & 0.00 \\
\hline $\mathrm{FeO}$ & 39.67 & 17.83 & 40.51 & 17.31 \\
\hline $\mathrm{MnO}$ & 0.46 & 0.21 & 0.51 & 0.18 \\
\hline $\mathrm{MgO}$ & 10.22 & 8.43 & 8.98 & 8.20 \\
\hline $\mathrm{CaO}$ & 0.86 & 21.14 & 0.88 & 20.92 \\
\hline $\mathrm{Na}_{2} \mathrm{O}$ & 0.01 & 0.35 & 0.02 & 0.35 \\
\hline Sum & 100.17 & 99.72 & 99.86 & 99.55 \\
\hline $\mathrm{Si}$ & 1.98 & 1.97 & 1.98 & 1.97 \\
\hline $\mathrm{Al}^{\mathrm{IV}}$ & 0.02 & 0.03 & 0.02 & 0.03 \\
\hline $\mathrm{Al}^{\mathrm{VI}}$ & 0.00 & 0.02 & 0.01 & 0.02 \\
\hline $\mathrm{Ti}$ & 0.00 & 0.00 & 0.00 & 0.00 \\
\hline $\mathrm{Cr}$ & 0.00 & 0.00 & 0.00 & 0.00 \\
\hline $\mathrm{Fe}^{3+}$ & 0.04 & 0.02 & 0.01 & 0.03 \\
\hline $\mathrm{Fe}^{2+}$ & 1.30 & 0.56 & 1.38 & 0.56 \\
\hline $\mathrm{Mn}$ & 0.02 & 0.01 & 0.02 & 0.01 \\
\hline $\mathrm{Mg}$ & 0.62 & 0.49 & 0.55 & 0.48 \\
\hline $\mathrm{Ca}$ & 0.04 & 0.88 & 0.04 & 0.87 \\
\hline $\mathrm{Na}$ & 0.00 & 0.02 & 0.00 & 0.02 \\
\hline $\mathrm{A}(\mathrm{en})$ & 0.081 & $\ldots$ & 0.102 & $\ldots$ \\
\hline $\mathrm{A}(\mathrm{fs})$ & 0.48 & $\ldots$ & 0.43 & . \\
\hline A(di) & $\ldots$ & 0.41 & $\ldots$ & 0.4 \\
\hline $\mathrm{A}($ hed) & $\ldots$ & 0.5 & $\ldots$ & 0.51 \\
\hline
\end{tabular}

${ }^{\mathrm{a}}$ Normalized to four cations.

${ }^{\mathrm{b}}$ Reintegrated from $30-50$ spot analyses.
Table 3. Garnet Analyses ${ }^{\mathrm{a}}$

\begin{tabular}{|c|c|c|c|c|}
\hline & 327.1 Core & 327.1 Rim & 134 Core & 134 Rim \\
\hline $\mathrm{SiO}_{2}$ & 37.66 & 37.79 & 37.37 & 38.54 \\
\hline $\mathrm{TiO}_{2}$ & 0.01 & 0.01 & 0.19 & 0.01 \\
\hline $\mathrm{Al}_{2} \mathrm{O}_{3}$ & 21.07 & 21.22 & 22.47 & 22.40 \\
\hline $\mathrm{Cr}_{2} \mathrm{O}_{3}$ & 0.00 & 0.00 & 0.17 & 0.36 \\
\hline $\mathrm{FeO}$ & 32.02 & 30.57 & 29.68 & 30.48 \\
\hline $\mathrm{MnO}$ & 1.36 & 1.22 & 0.38 & 0.26 \\
\hline $\mathrm{MgO}$ & 2.58 & 2.42 & 8.01 & 8.09 \\
\hline $\mathrm{CaO}$ & 6.80 & 7.91 & 1.36 & 1.20 \\
\hline $\mathrm{Na}_{2} \mathrm{O}$ & 0.02 & 0.01 & 0.03 & 0.06 \\
\hline Sum & 101.49 & 101.15 & 100.41 & 101.40 \\
\hline $\mathrm{Si}$ & 2.97 & 2.98 & 2.90 & 2.96 \\
\hline $\mathrm{Ti}$ & 0.00 & 0.00 & 0.01 & 0.00 \\
\hline $\mathrm{Al}$ & 1.96 & 1.97 & 2.05 & 2.02 \\
\hline $\mathrm{Cr}$ & 0.00 & 0.00 & 0.01 & 0.00 \\
\hline $\mathrm{Fe}^{3+}$ & 0.04 & 0.02 & 0.04 & 0.02 \\
\hline $\mathrm{Fe}^{2+}$ & 2.11 & 2.02 & 1.93 & 1.96 \\
\hline $\mathrm{Mn}$ & 0.09 & 0.08 & 0.02 & 0.02 \\
\hline $\mathrm{Mg}$ & 0.30 & 0.28 & 0.92 & 0.92 \\
\hline $\mathrm{Ca}$ & 0.57 & 0.67 & 0.11 & 0.10 \\
\hline Alm & 67.8 & 65.6 & 63.8 & 65.1 \\
\hline Gros & 18.4 & 21.7 & 3.7 & 3.3 \\
\hline Pyr & 9.7 & 9.3 & 30.0 & 30.0 \\
\hline Spes & 2.9 & 2.6 & 0.8 & 0.5 \\
\hline Uvar & 0.0 & 0.0 & 0.3 & 0.0 \\
\hline mg\# & 12.5 & 12.4 & 32.4 & 32.1 \\
\hline $\mathrm{a}(\mathrm{gr})$ & 0.0113 & 0.0200 & 0.0003 & 0.0001 \\
\hline a(pyr) & 0.0033 & 0.0033 & 0.0421 & 0.0325 \\
\hline $\mathrm{a}(\mathrm{alm})$ & 0.2962 & 0.2536 & 0.2799 & 0.3316 \\
\hline
\end{tabular}

${ }^{\mathrm{a}}$ Normalized to eight cations. 
Table 4. Staurolite Analyses ${ }^{\mathrm{a}}$

\begin{tabular}{lccc}
\hline & 326 Mean & 326 Core & 326 Rim \\
\hline $\mathrm{SiO}_{2}$ & 26.92 & 26.47 & 26.65 \\
$\mathrm{Al}_{2} \mathrm{O}_{3}$ & 55.28 & 55.95 & 55.37 \\
$\mathrm{TiO}_{2}$ & 0.47 & 0.51 & 0.48 \\
$\mathrm{FeO}$ & 14.37 & 14.77 & 14.35 \\
$\mathrm{MgO}$ & 1.58 & 1.60 & 1.63 \\
$\mathrm{MnO}$ & 0.54 & 0.46 & 0.59 \\
$\mathrm{ZnO}$ & 1.93 & 1.96 & 2.10 \\
$\mathrm{Na}{ }_{2} \mathrm{O}$ & 0.06 & 0.02 & 0.06 \\
$\mathrm{Cl}$ & 0.01 & 0.01 & 0.00 \\
$\mathrm{~F}$ & 0.03 & 0.03 & 0.00 \\
$\mathrm{Sum}$ & 101.24 & 101.77 & 101.22 \\
$\mathrm{Si}$ & 7.66 & 7.52 & 7.59 \\
$\mathrm{Al}$ & 0.34 & 0.48 & 0.41 \\
$\mathrm{Al}$ & 18.18 & 18.23 & 18.17 \\
$\mathrm{Ti}$ & 0.10 & 0.11 & 0.10 \\
$\mathrm{Fi}$ & 0.11 & 0.11 & 0.11 \\
$\mathrm{Fe}$ & $3 .+$ & 3.37 & 3.29 \\
$\mathrm{Mg}$ & 3.30 & 0.68 & 0.69 \\
$\mathrm{Zn}$ & 0.67 & 0.41 & 0.44 \\
$\mathrm{Ca}$ & 0.40 & 0.00 & 0.00 \\
$\mathrm{Na}$ & 0.00 & 0.01 & 0.03 \\
$\mathrm{Cl}$ & 0.03 & 0.01 & 0.00 \\
$\mathrm{~F}$ & 0.01 & 0.05 & 0.00 \\
$\mathrm{a}(\mathrm{fst})$ & 0.06 & 0.43 & 0.43 \\
$\mathrm{~A}(\mathrm{mst})$ & 0.43 & 0.015 & 0.013 \\
\hline & 0.013 & &
\end{tabular}

${ }^{\mathrm{a} A s s u m i n g} 3.5 \% \mathrm{Fe}^{3+}$, normalized to $48 \mathrm{O}$ atoms.

$\left(\mathrm{An}_{40}-\mathrm{An}_{42}\right)$, and quartz. Large plagioclase grains in the matrix are zoned as well, with core compositions of $\mathrm{An}_{45}$ decreasing to $\mathrm{An}_{35}$ toward the rims $(\sim 75 \mu \mathrm{m}$ thick $)$, suggesting that plagioclase inclusions in garnet record conditions similar to those preserved in matrix plagioclase cores (Figure 8). Clinopyroxene and orthopyroxene are present as euhedral grains that lie within the foliation plane. Exsolved textures in pyroxene reflect unmixing during slow cooling, with original compositions recovered through standard reintegration techniques [Bohlen and Essene, 1977]. Clinopyroxene inclusions in garnet are surrounded by $\mathrm{Mg}$-Fe diffusion profiles, probably reflecting ongoing $\mathrm{Mg}-\mathrm{Fe}$ exchange during retrograde cooling. In order to recover peak temperatures from the inclusions, the area of the haloes was determined by image analysis and excess Fe from this area was reintegrated with the composition of inclusions (Figure 6d). The reintegration yields temperatures that were higher by $\sim 50^{\circ} \mathrm{C}$ than temperatures obtained without reintegration. Thermobarometric calculations (Figure 7) for the garnet core and inclusion assemblage gives $810^{\circ} \mathrm{C}$ at pressures of $7.5 \mathrm{MPa}(\mathrm{SdT} 150, \mathrm{SdP} 1.8$, Sdfit 0.04, correlation 0.90), derived from garnet-pyroxene exchange reactions as well as garnet-pyroxene-plagioclase mass transfer reactions (e.g., GADS [Moecher et al., 1988]).

[16] In using the core-matrix and rim-contact assemblages to calculate P-T conditions, it is uncertain whether zoning in garnet and plagioclase is due to prograde changes in pressure or to retrograde reactions such as the late appearance of hornblende or $\mathrm{K}-\mathrm{Na}$ exchange between $\mathrm{K}$-feldspar and plagioclase. Given the possibility of retrograde, masstransfer and exchange reactions, the pressure increase of $\sim 3 \mathrm{kbar}$ indicated by growth zoning in garnet and plagio-
Table 5. Sheet Silicate Analyses ${ }^{\mathrm{a}}$

\begin{tabular}{|c|c|c|c|c|c|}
\hline & 127 Matrix & 134 Contact & $\begin{array}{c}134 \\
\text { Matrix }\end{array}$ & $\begin{array}{c}326 \\
\text { Biotite }\end{array}$ & $\begin{array}{c}326 \\
\text { Muscovite }\end{array}$ \\
\hline $\mathrm{SiO}_{2}$ & 36.64 & 36.16 & 35.80 & 36.64 & 48.48 \\
\hline $\mathrm{TiO}_{2}$ & 2.43 & 1.87 & 4.21 & 1.69 & 0.12 \\
\hline $\mathrm{Al}_{2} \mathrm{O}_{3}$ & 18.72 & 17.55 & 16.08 & 20.40 & 37.57 \\
\hline $\mathrm{Cr}_{2} \mathrm{O}_{3}$ & 0.00 & 0.19 & 0.16 & 0.00 & 0.00 \\
\hline $\mathrm{FeO}$ & 18.93 & 8.90 & 14.30 & 19.50 & 1.18 \\
\hline $\mathrm{MgO}$ & 11.47 & 18.72 & 13.54 & 10.25 & 0.79 \\
\hline $\mathrm{MnO}$ & 0.22 & 0.14 & 0.00 & 0.18 & 0.03 \\
\hline $\mathrm{BaO}$ & 0.00 & 0.19 & 0.00 & 0.00 & 0.00 \\
\hline $\mathrm{CaO}$ & 0.03 & 0.00 & 0.01 & 0.02 & 0.00 \\
\hline $\mathrm{Na}_{2} \mathrm{O}$ & 0.13 & 0.13 & 0.03 & 0.14 & 0.27 \\
\hline $\mathrm{K}_{2} \mathrm{O}$ & 9.92 & 10.38 & 10.46 & 9.73 & 9.68 \\
\hline $\mathrm{F}$ & 0.38 & 2.29 & 0.63 & 0.33 & 0.11 \\
\hline $\mathrm{Cl}$ & 0.11 & 0.14 & 0.21 & 0.10 & 0.02 \\
\hline Sum & 98.30 & 95.66 & 94.28 & 98.38 & 98.25 \\
\hline $\mathrm{Si}$ & 5.49 & 5.21 & 5.56 & 5.48 & 6.18 \\
\hline $\mathrm{Al}^{\mathrm{IV}}$ & 2.51 & 2.78 & 2.44 & 2.52 & 1.82 \\
\hline $\mathrm{Al}^{\mathrm{VI}}$ & 0.79 & 0.19 & 0.51 & 1.08 & 3.81 \\
\hline $\mathrm{Ti}$ & 0.27 & 0.20 & 0.49 & 0.19 & 0.01 \\
\hline $\mathrm{Cr}$ & 0.00 & 0.02 & 0.02 & 0.00 & 0.00 \\
\hline $\mathrm{Fe} 3+^{\mathrm{b}}$ & 0.19 & 0.08 & 0.15 & 0.19 & 0.11 \\
\hline $\mathrm{Fe}$ & 2.16 & 0.98 & 1.69 & 2.23 & 0.00 \\
\hline $\mathrm{Mg}$ & 2.56 & 4.02 & 3.14 & 2.29 & 0.15 \\
\hline $\mathrm{Mn}$ & 0.03 & 0.02 & 0.00 & 0.02 & 0.00 \\
\hline $\mathrm{Ba}$ & 0.00 & 0.01 & 0.00 & 0.00 & 0.00 \\
\hline $\mathrm{Ca}$ & 0.00 & 0.00 & 0.00 & 0.00 & 0.00 \\
\hline $\mathrm{Na}$ & 0.04 & 0.04 & 0.01 & 0.04 & 0.07 \\
\hline $\mathrm{K}$ & 1.90 & 1.91 & 2.07 & 1.86 & 1.57 \\
\hline $\mathrm{F}$ & 0.18 & 1.04 & 0.31 & 0.16 & 0.04 \\
\hline $\mathrm{Cl}$ & 0.03 & 0.03 & 0.06 & 0.03 & 0.00 \\
\hline Mg* & 54.1 & 80.2 & 64.9 & 50.3 & 98.0 \\
\hline
\end{tabular}

${ }^{a}$ Normalized to 22 oxygen atoms.

${ }^{\mathrm{b}}$ Estimated from Guidotti and Dyar [1991].

Table 6. Oxide Analyses ${ }^{\mathrm{a}}$

\begin{tabular}{lcc}
\hline & 134 Ilmenite & 134 Spinel \\
\hline $\mathrm{FeO}$ & 43.95 & 22.49 \\
$\mathrm{TiO}_{2}$ & 51.56 & 0.03 \\
$\mathrm{Al}_{2} \mathrm{O}_{3}$ & 0.02 & 62.66 \\
$\mathrm{MnO}$ & 1.15 & 9.50 \\
$\mathrm{MgO}$ & 0.03 & 0.02 \\
$\mathrm{ZnO}$ & 0.05 & 5.28 \\
$\mathrm{Cr}_{2} \mathrm{O}_{3}$ & 0.05 & 0.22 \\
$\mathrm{SiO}_{2}$ & 0.02 & 0.03 \\
$* \mathrm{~V}_{2} \mathrm{O}_{3}$ & 0.55 & 0.34 \\
$\mathrm{NiO}_{\mathrm{Sum}}$ & 0.00 & 0.00 \\
$\mathrm{Fe}$ & 97.38 & 100.57 \\
$\mathrm{Fe}$ & 0.00 & 0.00 \\
$\mathrm{Ti}$ & 0.95 & 0.51 \\
$\mathrm{Al}$ & 1.01 & 0.00 \\
$\mathrm{Mn}$ & 0.00 & 1.99 \\
$\mathrm{Mg}$ & 0.03 & 0.00 \\
$\mathrm{Ca}$ & 0.00 & 0.38 \\
$\mathrm{Cr}$ & 0.00 & 0.00 \\
$\mathrm{Si}$ & 0.00 & 0.00 \\
$\mathrm{~V}^{\mathrm{b}}$ & 0.00 & 0.00 \\
$\mathrm{Zn}$ & 0.01 & 0.01 \\
& 0.00 & 0.11 \\
\hline
\end{tabular}

${ }^{\mathrm{a}}$ Normalized to two cations.

${ }^{\mathrm{b}} \mathrm{V}$ corrected for Ti interference in ilmenite. 


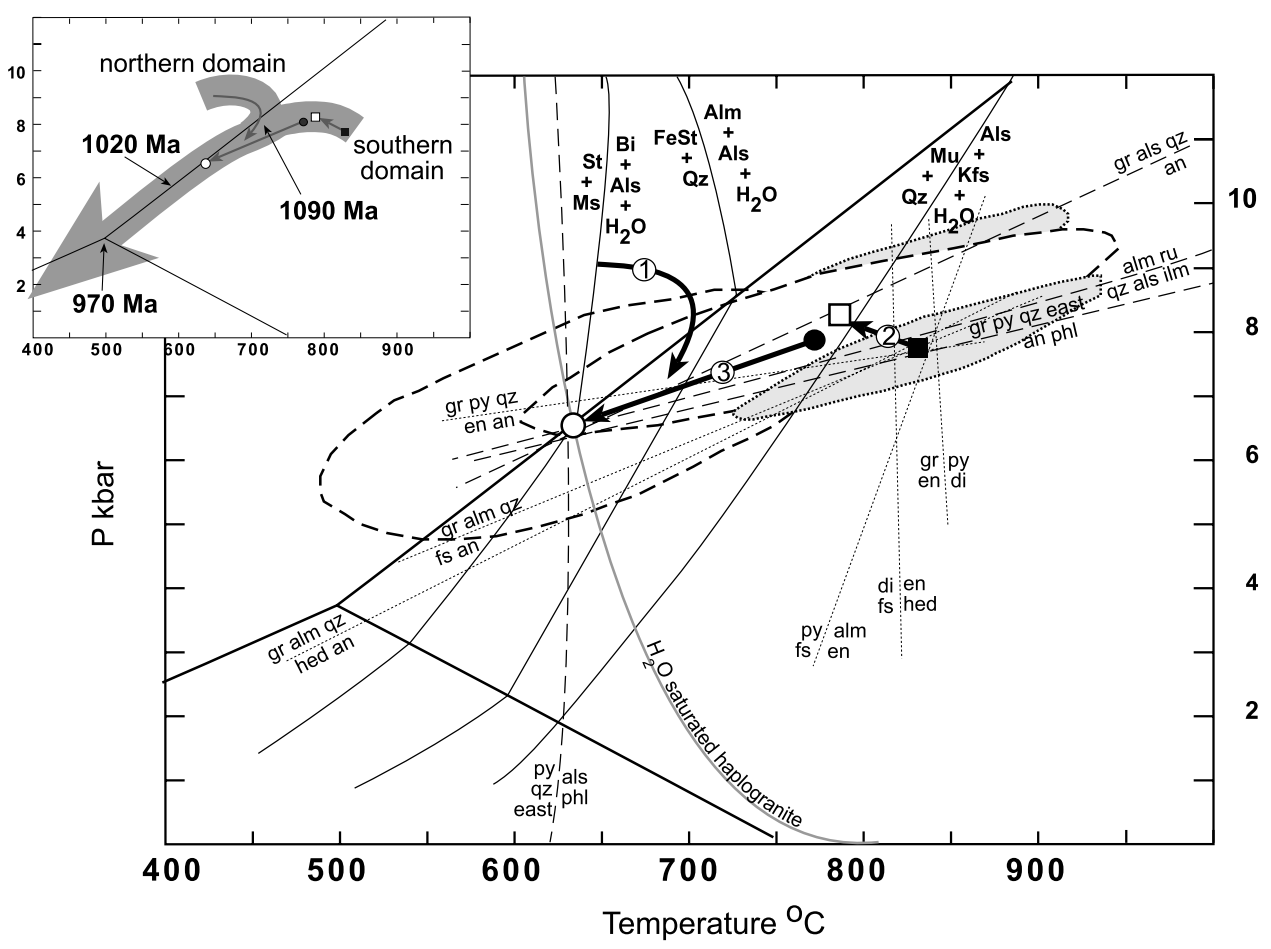

Figure 7. Compiled P-T information for the northern and southern portions of the Nova Brasilândia belt. Temperature limits on the prograde sequence for the northern domain are indicated by two stauroliteout reactions (solid black lines crossing $\mathrm{AlSi}_{2} \mathrm{O}_{5}$ phase equilibria with boldface text) [Dutrow and Holdaway, 1989]. Dotted lines indicate representative reactions used for sample 327 (squares, shaded error ellipses with dotted lines), and dashed lines indicate reactions used for sample 134 (circles, open error ellipses with dashed lines). P-T conditions for solid symbols are from core-inclusion assemblages and open symbols are from rim-contact assemblages. Top inset shows separate P-T loops for both portions of the belt, with uniform cooling indicated by single path with geochronological constraints for cooling through hornblende's blocking temperature.

clase calculated using the garnet-pyroxene-plagioclasequartz geobarometers of Moecher et al. [1988], probably represents a maximum estimate. Average P-T conditions derived from Thermocalc 2.1 using the same reactions as before (Figure 7) indicate a slight decrease in temperature and increase in pressure from conditions recorded by the core assemblage (arrow 2, Figure 7 ), $780^{\circ} \mathrm{C}$ at $8 \mathrm{MPa}(\mathrm{SdT}$ 110, SdP 1.3, Sdfit 0.7, correlation 0.83).

[17] Sample Et-134 is a sillimanite-garnet gneiss with the assemblage Gar + Sil + spinel + Plag + Qtz + Bi + Ru + Ilm. Sillimanite, spinel, quartz, ilmenite, and plagioclase $\left(\mathrm{An}_{28^{-}}\right.$ $\mathrm{An}_{31}$ ) form large inclusions within the garnet and are also found as matrix phases. Rutile is observed only in the matrix, typically in close association with ilmenite. Plagioclase in the mylonitic matrix of the sample ranges in composition from $\mathrm{An}_{20}$ to $\mathrm{An}_{25}$. Garnet profiles are homogeneous with a slight decrease $(1 \mathrm{~mol} \%)$ in grossular

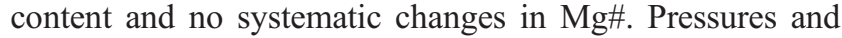
temperatures calculated for the coexisting core-inclusion assemblage are $770^{\circ} \mathrm{C}$ at $8 \mathrm{MPa}$ (SdT 140 , SdP $1.3 \mathrm{MPa}$, Ssdfit 1.2, correlation 0.81), based on GASP and garnetbiotite reactions. The rim-matrix assemblage for sample 134 $(\mathrm{Gar}+\mathrm{Plag}+\mathrm{Qz}+\mathrm{Sil}+\mathrm{Bi}+\mathrm{Ru}+\mathrm{Ilm})$ yielded average temperatures of $630^{\circ} \mathrm{C}$ at $6 \mathrm{MPa}(\mathrm{SdT} 130, \mathrm{SdP} 1.5$, Sdfit
1.9, correlation 0.62) based on GRIPS, GRAIL, and GASP geobarometers and garnet-biotite thermometry. The P-T differences between core and rim assemblages indicate cooling and decreasing pressures (arrow 3, Figure 7). There is no textural evidence for late kyanite in the retrograde assemblage, as predicted by the calculated P-T conditions.

[18] In summary, the metamorphic conditions for the northern and southern domains show distinct variations in grade and in evolving P-T conditions. A prograde sequence is preserved in the northern domain, where metamorphic conditions never reached the granulite facies, with the breakdown of kyanite consistent with decreasing pressure. The clockwise loop implied by this sequence is typical of terranes that have undergone crustal thickening due to imbrication [England and Thompson, 1984]. In contrast, metamorphic conditions in the granulitic southern domain register increasing pressures, coupled with a slight decrease in temperature, followed by exhumation (counterclockwise loop). The difference in evolving P-T conditions observed along a N-S transect reflect separate processes by which orogenesis can result in crustal thickening; imbrication through deep seated thrust faulting and the development of a volcanic overburden caused by melt extraction from deeper, granulitic source rocks, a process 

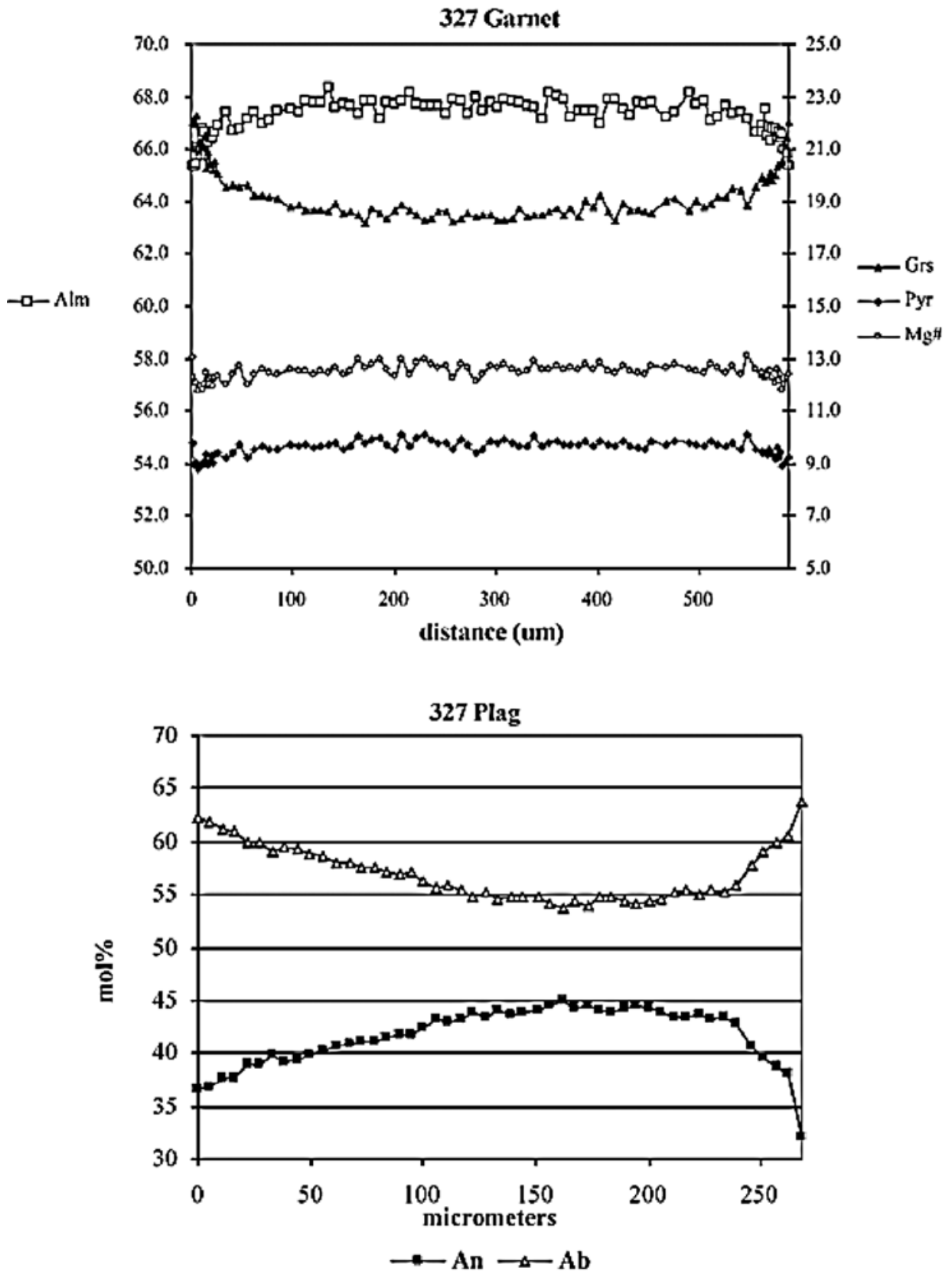

Figure 8. Mineral zoning patterns in (top) garnet and (bottom) plagioclase two-pyroxene garnet granulite (sample 327.1), suggesting garnet growth at the expense of the anorthitic component of plagioclase under increasing pressures.

which transfers heat to rocks stratigraphically higher in the crustal pile, driving prograde reactions [e.g., Valley, 1992]. That both processes were at work in the transpressional NBMB suggests a tectonic collision with some degree of obliquity.

\section{Geochronology}

[19] Samples were collected from throughout the NBMB for both ${ }^{40} \mathrm{Ar} /{ }^{39} \mathrm{Ar}$ and $\mathrm{U} / \mathrm{Pb}$ geochronology. Argon analysis was performed at the University of
Michigan (see Tohver et al., 2002 for methods) and $\mathrm{U} / \mathrm{Pb}$ analysis was undertaken at the Zentrallabor für Geochronologie at the Universität Münster, in Münster, Germany. Rocks were crushed and sieved for the 100$500 \mu \mathrm{m}$ size fraction, which was washed with deionized water, dried, and passed through heavy liquids to remove lighter fractions. A Frantz magnetic separator was used to divide diamagnetic and paramagnetic fractions. Individual titanite and monazite grains were hand-picked under a binocular microscope, avoiding grains with visible inclusions. 
Table 7. U/Pb Data for the Nova Brasilândia Belt ${ }^{\mathrm{a}}$

\begin{tabular}{|c|c|c|c|c|c|c|c|c|c|c|c|}
\hline \multirow[b]{2}{*}{ Sample } & \multirow[b]{2}{*}{$\mathrm{U}, \mathrm{ppm}$} & \multirow[b]{2}{*}{$\mathrm{Pb}, \mathrm{ppm}$} & \multirow[b]{2}{*}{${ }^{206} \mathrm{~Pb} /{ }^{204} \mathrm{~Pb}$} & \multirow[b]{2}{*}{${ }^{208} \mathrm{~Pb} /{ }^{206} \mathrm{~Pb}$} & \multirow[b]{2}{*}{${ }^{207} \mathrm{~Pb} /{ }^{206} \mathrm{~Pb}$} & \multirow[b]{2}{*}{${ }^{207} \mathrm{~Pb} /{ }^{235} \mathrm{U}$} & \multirow[b]{2}{*}{${ }^{206} \mathrm{~Pb} /{ }^{238} \mathrm{U}$} & \multirow[b]{2}{*}{ Rho } & \multicolumn{3}{|c|}{ Age Data, Ma } \\
\hline & & & & & & & & & ${ }^{206} \mathrm{~Pb} /{ }^{238} \mathrm{U}$ & ${ }^{207} \mathrm{~Pb} /{ }^{235} \mathrm{U}$ & ${ }^{207} \mathrm{~Pb} /{ }^{206} \mathrm{~Pb}$ \\
\hline $16 \mathrm{t}$. & 14.65 & 6.16159 & 164.5 & 1.367 & $0.07323 \pm 0.0005$ & $1.705 \pm 0.015$ & $0.1688 \pm 0.0007$ & 0.658 & 1006 & 1011 & 1020 \\
\hline ron135 t. & 0.4355 & 0.1096 & 252.8 & 0.5048 & $0.07469 \pm 0.0005$ & $1.769 \pm 0.039$ & $0.1718 \pm 0.0036$ & 0.954 & 1022 & 1034 & 1060 \\
\hline 319 mon & 79.59 & 22.16 & 239.0 & 0.5638 & $0.07225 \pm 0.0004$ & $1.674 \pm 0.025$ & $0.1680 \pm 0.0022$ & 0.935 & 1001 & 999 & 993 \\
\hline 134 mon & 4600 & 3592 & 9736 & 3.801 & $0.07599 \pm 0.0001$ & $1.935 \pm 0.008$ & $0.1847 \pm 0.0007$ & 0.936 & 1093 & 1093 & 1095 \\
\hline 134 mon & 176.9 & 138.5 & 10562 & 3.801 & $0.07607 \pm 0.0001$ & $1.942 \pm 0.007$ & $0.1851 \pm 0.0006$ & 0.920 & 1095 & 1096 & 1097 \\
\hline GIL t & $\ldots$ & 31.88 & 839.0 & 0.6011 & $0.07463 \pm 0.0002$ & & & & & $\ldots$ & 1059 \\
\hline 326 mon & 402.4 & 170.9 & 877.0 & 1.518 & $0.07552 \pm 0.0002$ & $1.918 \pm 0.008$ & $0.1842 \pm 0.0006$ & 0.861 & 1090 & 1088 & 1082 \\
\hline Gr13 t & 9.891 & 3.005 & 700.0 & 0.5712 & $0.07503 \pm 0.0002$ & $2.096 \pm 0.022$ & $0.2026 \pm 0.0020$ & 0.977 & 1189 & 1148 & 1069 \\
\hline Gr11 t & 146.2 & 51.95 & 112.9 & 0.6661 & $0.07560 \pm 0.0007$ & $1.756 \pm 0.021$ & $0.1684 \pm 0.0008$ & 0.626 & 1004 & 1029 & 1085 \\
\hline
\end{tabular}

a Abbreviations are as follows: mon, monazite; $\mathrm{t}$, titanite. Multigrain aliquots were handpicked from heavy liquid separates using a binocular microscope. Monazite analyses comprise $3-5$ of $\sim 50-300 \mu \mathrm{m}$ grains and titanite analyses $0.5-5 \mathrm{mg}$ aliquots of $\sim 30-500 \mu \mathrm{m}$ grains. All errors are calculated at the $2 \sigma$ level. Mass fractionation was determined to be 1.001 per atomic mass unit and analytical blanks ranged from $30-120$ picograms $\mathrm{Pb}$.

[20] Mineral fractions were washed, weighed, and spiked with a mixed ${ }^{233} \mathrm{U}^{205} \mathrm{~Pb}$ tracer before being placed in $3 \mathrm{~mL}$ Teflon ${ }^{\text {TM }}$ vials for digestion ( $\mathrm{HF}$ and $\mathrm{HNO}_{3}$ for titanite, $\mathrm{HNO}_{3}$ and $\mathrm{HCl}$ for monazite). The sample vial were placed in Teflon ${ }^{\mathrm{TM}}$-lined, Krogh style bombs at $200^{\circ} \mathrm{C}$ for $24-$ 72 hours, after which the dissolved samples were dried. Both $\mathrm{U}$ and $\mathrm{Pb}$ were separated in $100 \mu \mathrm{L}$ Teflon ${ }^{\mathrm{TM}}$ columns with Dowex $1 \times 8$ resin beads using $\mathrm{HCl}-\mathrm{HNO}_{3}$ and $\mathrm{HCl}-\mathrm{HBr}$ anion exchange chemistry, respectively. Dried U and $\mathrm{Pb}$ fractions were redissolved in concentrated $\mathrm{HCl}$ and loaded onto separate Re filaments using the phosphoric acid-silica gel technique. Fractionation during thermal ionization was corrected by measurement of $\mathrm{Pb}$ standard NBS-982 and the U standard U-500. Both $\mathrm{U}$ and $\mathrm{Pb}$ were analyzed for isotopic composition using a thermal ionization VG Sector 54 multicollector mass spectrometer. Most masses were measured in Faraday cups with ${ }^{204} \mathrm{~Pb}$ measured on the Daly detectors for samples with low amounts of common $\mathrm{Pb}$.

[21] Monazite and titanite grains from six samples throughout the metasedimentary belt were selected for $\mathrm{U} / \mathrm{Pb}$ analysis (Table 7). Results from these analyses are plotted on U-Pb concordia diagrams in Figure 9. The intercept for discordant aliquots was determined from a line forced through the origin. Most monazite samples are characterized by radiogenic $\mathrm{Pb}$ in excess of $98 \%$ of total $\mathrm{Pb}$, but titanite shows significant incorporation of common $\mathrm{Pb}$, with ${ }^{206} \mathrm{~Pb} /{ }^{204} \mathrm{~Pb}$ ratios as low as $113(85 \%$ radiogenic $\mathrm{Pb})$. Common $\mathrm{Pb}$ correction for all samples was made using Stacey and Kramer's two-stage $\mathrm{Pb}$ evolution curve (1975) with values at $1.0 \mathrm{Ga}$ of 17.06 for ${ }^{206} \mathrm{~Pb} /{ }^{204} \mathrm{~Pb}$ and 15.51 for ${ }^{207} \mathrm{~Pb} /{ }^{204} \mathrm{~Pb}$ (Table 7). The resultant titanite ages are similar for all samples, regardless of the amount of common $\mathrm{Pb}$ initially incorporated, suggesting that isotopic values of initial $\mathrm{Pb}$ values were reasonably uniform for the region. Two monazite ages are concordant (sample 134, U/Pb age $1095.8 \pm 5.3 \mathrm{Ma}$; and sample $319, \mathrm{U} / \mathrm{Pb}$ age $993^{+11} /_{-12} \mathrm{Ma}$ ) with one sample plotting slightly above the $\mathrm{U}-\mathrm{Pb}$ concordia (sample 326, ${ }^{207} \mathrm{~Pb} /{ }^{206} \mathrm{~Pb}$ age $1082.4^{+6.2} /{ }_{-6.4} \mathrm{Ma}$ ). The $\sim 100 \mathrm{Ma}$ variation in monazite ages is difficult to explain, if one assumes that all of these ages represent simple cooling. One possibility for the youngest age of $\sim 993 \mathrm{Ma}$ is that monazite grew below its closure temperature through dynamic recrystallization. This scenario is supported by the observation that most titanite, which has a lower closure temperature than monazite, yields ages in the range of $1020-1084 \mathrm{Ma}$, which is older than the youngest monazite. Most titanite grains are $93-97 \%$ concordant with the upper limit on the age range of titanite defined by sample GR-11, which has a relatively low ${ }^{206} \mathrm{~Pb} /{ }^{204} \mathrm{~Pb}$ ratio of 113 . The dependence of this sample on the common $\mathrm{Pb}$ correction renders the $7.5 \%$ discordant age less reliable.

[22] Continued cooling from the peak of regional metamorphism is recorded by hornblende ages that cluster in the $\sim 970$ Ma range and biotite ages in the $\sim 940$ Ma range. Argon isotope data are available as auxiliary material ${ }^{1}$. Spectra from step-heating of minerals for ${ }^{40} \mathrm{Ar} /{ }^{39} \mathrm{Ar}$ analysis are shown in Figure 10. As can be seen from the degassing spectra, after the initial, low temperature steps, most samples exhibit undisturbed plateaus characterized by a minimal compositional variation, suggestive of a simple cooling history with little indication of mineralogical change during retrograde metamorphism. The geographic distribution of all age data is shown in Figure 3. The regional distribution of ages shows no correlation with metamorphic grade, suggesting that the studied portion of the Nova Brasilândia was exhumed uniformly. Cooling from the high-grade event was on the order of $2^{\circ}-2.5^{\circ} \mathrm{C} / \mathrm{Ma}$, rates that are typical of high-grade terranes of the North American Grenville Province [Cosca et al., 1991; Mezger et al., 1992]. However, the large difference between the titanite ages and hornblende ages, as well as the reset 996 Ma monazite age suggests that there may have been a phase of deformation at $1.0 \mathrm{Ga}$.

\section{Discussion}

[23] The Nova Brasilândia metasedimentary belt records the effects of high-grade metamorphism at circa $1.09 \mathrm{Ga}$. The sequence of metamorphism preserved in the northern domain suggests a clockwise P-T loop, the product of crustal thickening through imbrication [England and

\footnotetext{
${ }^{1}$ Auxiliary material is available at $\mathrm{ftp} / / \mathrm{ftp}$. agu.org/apend/tc/ 2003 TC001563.
} 

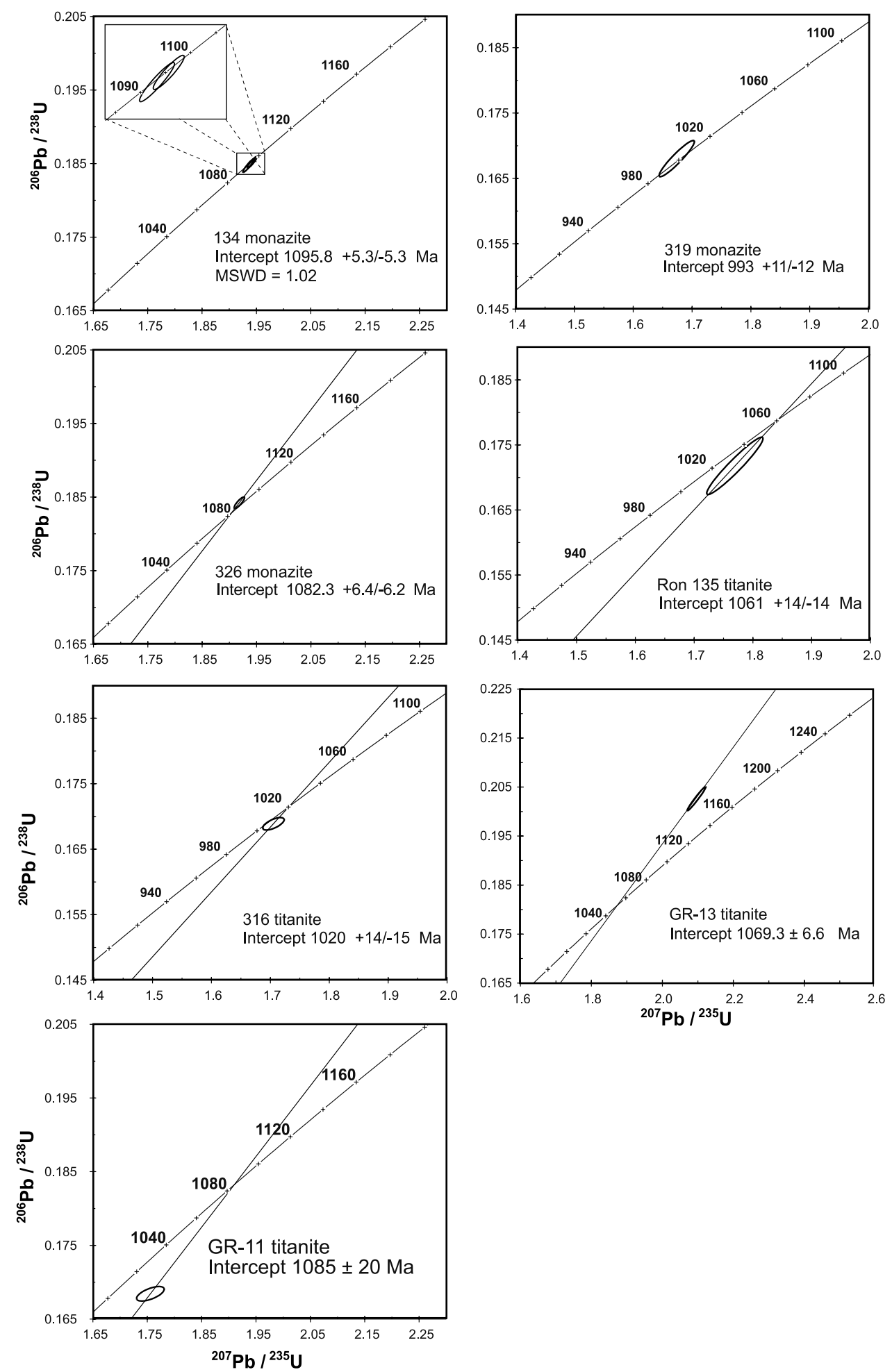

Figure 9. U-Pb concordia diagrams for monazites and titanites from Nova Brasilândia.

Thompson, 1984]. Assuming an average crustal thickness of $30-35 \mathrm{~km}$, the exhumation of the NBMB rocks from midcrustal depths $(20-30 \mathrm{~km})$ implies that metamorphism was the product of collision-related deformation. The deformation is registered in the development of deep-seated thrusting and accompanying strike-slip motion, indicating a transpressive tectonic environment. The absence of older basement rocks that have been reworked during deformation means that the Nova Brasilândia belt records a single orogenic cycle during late Mesoproterozoic times. This 

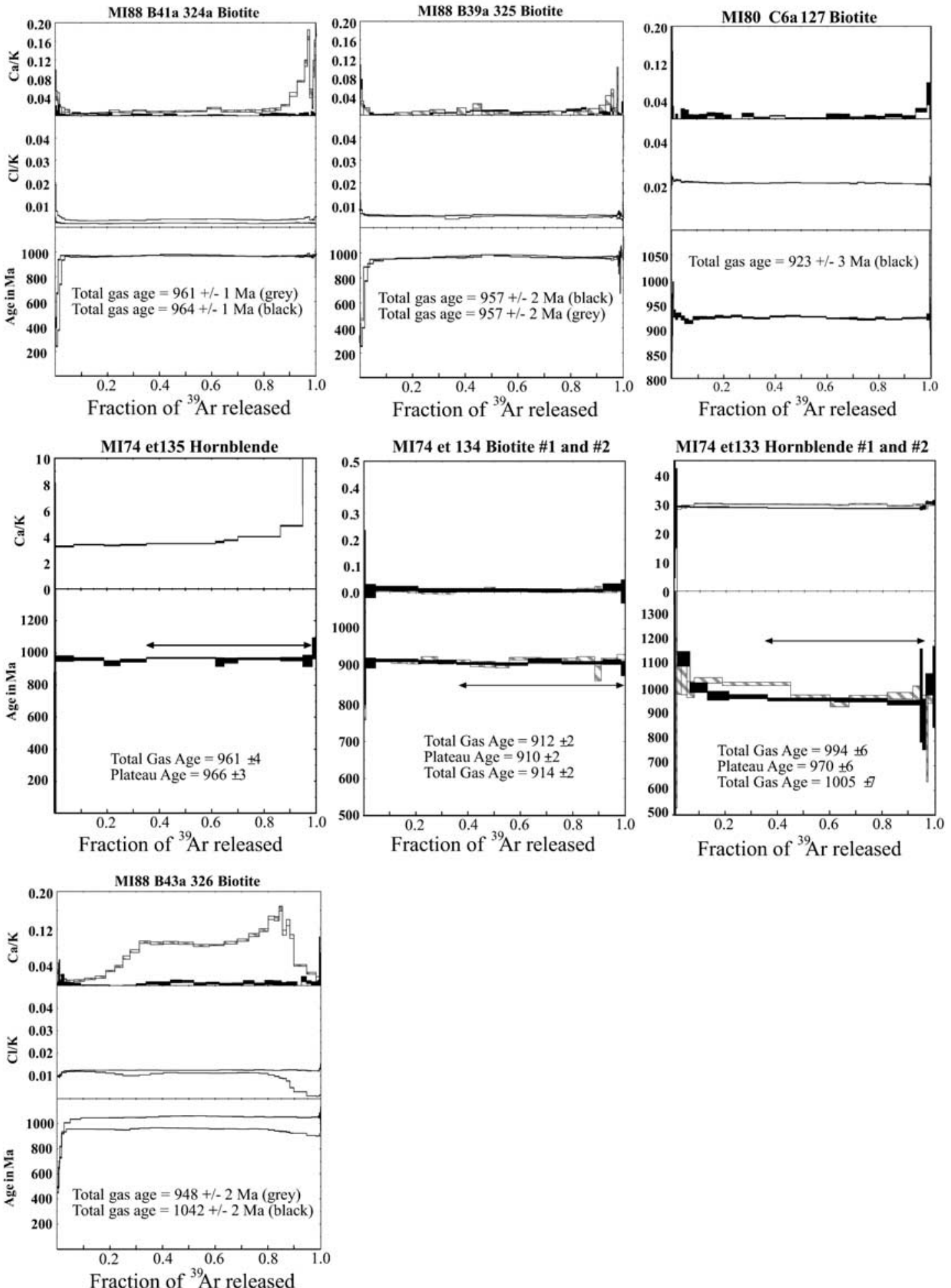

Figure 10. The ${ }^{40} \mathrm{Ar} /{ }^{39} \mathrm{Ar}$ age spectra for minerals from the Nova Brasilândia metasedimentary belt showing homogeneous mineral compositions and insignificant variation in ages measured from replicate samples. 
monocyclic history contrasts strongly with the older, polycyclic Amazon basement to the north, where basement rocks were being actively deformed in a strike-slip environment as recently as $1.13 \mathrm{Ga}$. The lack of evidence in the NBMB for the older deformation episode that affected the cratonic basement to the north has a simple explanation: the sedimentary protolith of the NBMB was not in place until after the last tectonometamorphic episode that affected the Amazon basement rocks at $1.19-1.13 \mathrm{Ga}$. This scenario is in agreement with the maximum limits on the NBMB depositional age, constrained by $1211 \pm 18 \mathrm{Ma}$ age of the youngest detrital zircon present in the metamorphosed greywackes [Santos et al., 2000].

[24] The location of the NBMB on the boundary zone marking the limit of the occurrence of the granitoid basement rocks of the Amazon craton becomes significant in light of aeromagnetic data from this region. Aeromagnetic data from the SW Amazon craton were collected in two stages, 1975-1979 and 1988-1995. Total field magnetic surveys were conducted by airborne proton precession magnetometer surveys from altitudes that ranged from $150 \mathrm{~m}$ for the first phase of data collection to $1020 \mathrm{~m}$, for the second phase. Field measurement were taken at intervals of 1-2 $\mathrm{s}$, translating to a ground spacing of measurements of $60-120 \mathrm{~m}$. Transects in a N-S direction were spaced over $1 \mathrm{~km}$ intervals for the first phase, with up to $20 \mathrm{~km}$ intervals for the second phase. The first phase of collection was undertaken by the Companhia de Pesquisa de Recursos Minerais (CPRM) under contract to the Departamento Nacional de Produção Mineral (DNPM) and the second phase was undertaken by Petrobras. These data sets have been made available by the CPRM at http:// www.cprm.gov.br. A compilation of the results of seven projects (Pacaás Novos (1978), Serra dos Parecis, Cabeceira do Rio Guaporé, Rio do Sangue, Reserva Indígena Juruena, Bacia dos Parecis, and Bacia dos Parecis (sub Bacia Alto Xingu)/Bloco 1) is shown in Figure 11.

[25] The subsurface geology of the exposed Nova Brasilândia belt is characterized by two strong magnetic gradients that outline the northern and southern boundaries of the belt. The magnitude of the anomalies is consistent with the presence of small, mafic bodies at depth, such as the amphibolitized sills and dikes that are exposed throughout the belt. The general E-W trend of the anomalies is concordant with the trend of regional geology. This E-W trend is also observed to mark the southern boundary of the polycyclic Amazon basement (central portion of Figure 11), which is characterized by a strong positive anomaly with a wavelength of $\sim 30 \mathrm{~km}$. The amplitude of the associated negative anomaly to the $\mathrm{S}$ is attenuated where covered by the sediments of the Pimenta Bueno graben, but becomes more pronounced to the $\mathrm{E}$. This strong anomaly probably is probably associated with the presence of mafic rocks [e.g., amphibolitic bodies of Figure 2] along the $1000 \mathrm{~km}$ length of the E-W trending, first order feature (i.e., the Ciriququi mafic arc of Litherland et al. [1986]). The anomaly is continuous for $600 \mathrm{~km}$ beneath the continental sediments of the Serra dos Parecis Formation (Kt) until the nearly orthogonal intersection with the Brasiliano-aged Paraguai belt, recognized to form the boundary of the Amazon craton by late Neoproterozoic times [Alvarenga and Trompette, 1993; Alvarenga et al., 2000]. It is noted that the E-W magnetic lineament that defines the length of the NBMB has served as the locus for at least three episodes of sedimentation as described in a previous section. In addition, the regional trend of kimberlite occurrences overlaps with the magnetic lineament, suggestive of a zone of crustal weakness reactivated during sedimentation and later exploited during kimberlite emplacement [Wilding et al., 1991; Svisero, 1995].

[26] The concordance of magnetic anomaly and surface geology of the adjacent NBMB suggest that the two are correlated and the belt extends $\sim 1000 \mathrm{~km}$ farther to the east than its present exposure. Age correlations from borehole samples $\sim 750 \mathrm{~km}$ to the west suggest an overall E-W length of $\sim 2000 \mathrm{~km}$. In contrast, the Aguapeí belt (NNW trend) is a minor map feature with no clear linkage to the Nova Brasilândia belt. The disjunction between these two metasedimentary belts suggests that they are not connected by contiguous lithologies and were not tectonically linked, an interpretation that is corroborated by geochronological data from the two belts. Whereas the ${ }^{40} \mathrm{Ar} /{ }^{39} \mathrm{Ar}$ ages for biotite from the Nova Brasilândia belt reported in this study are similar to $\mathrm{K} / \mathrm{Ar}$ ages of white mica from the Aguapeí belt reported by Geraldes et al. [1997]; the former reflect cooling from a high-grade deformation event at $1.09 \mathrm{Ga}$, the latter reflect the absolute timing of deformation under lower greenschist facies conditions. In the latest Mesoproterozoic, the NBMB was marked by the deposition of deep-water sediments $(<1215 \mathrm{Ma})$ followed by high-grade deformation and metamorphism at $\sim 1.09 \mathrm{Ga}$. The deformation of the cratonic basement to the north $(1.18-1.15 \mathrm{Ga})$ and concurrent sedimentation in the NBMB suggests a genetic link. We propose that this boundary represents the margin for the Amazon craton prior to the late Mesoproterozoic accretion of the Paragua craton to the Amazon craton. How far apart the Amazon and Paragua cratons were prior to this collision and whether they share a geological history prior to the late Mesoproterozoic is unknown.

[27] Regional stratigraphic correlations are an important test of the hypothesis that the NBMB is a suturing collisional belt. Thus the question of whether the NBMB sedimentary protolith sequence is related to the Aguapeí Group is important to resolving the paleogeographic position of the Amazon craton relative to the Paragua craton. Unrelated stratigraphies would imply no geographic proximity between the respective depocenters, a scenario permitted by the suture hypothesis. On the other hand, correlating the sequences would signify that the Amazon and Paragua cratons were geologically linked well before the end of Mesoproterozoic times. One current model for the development of the Nova Brasilândia belt interprets the sedimentary protolith of the belt as having been deposited in a rift between the Amazon craton and the Paragua craton [Rizzotto, 2001]. The rift is assumed to extend $400 \mathrm{~km}$ to the SE, encompassing the Aguapeí sediments and implies a tectonic connection between the Amazon and Paragua cratons. The Aguapeí Group itself has been assigned an 


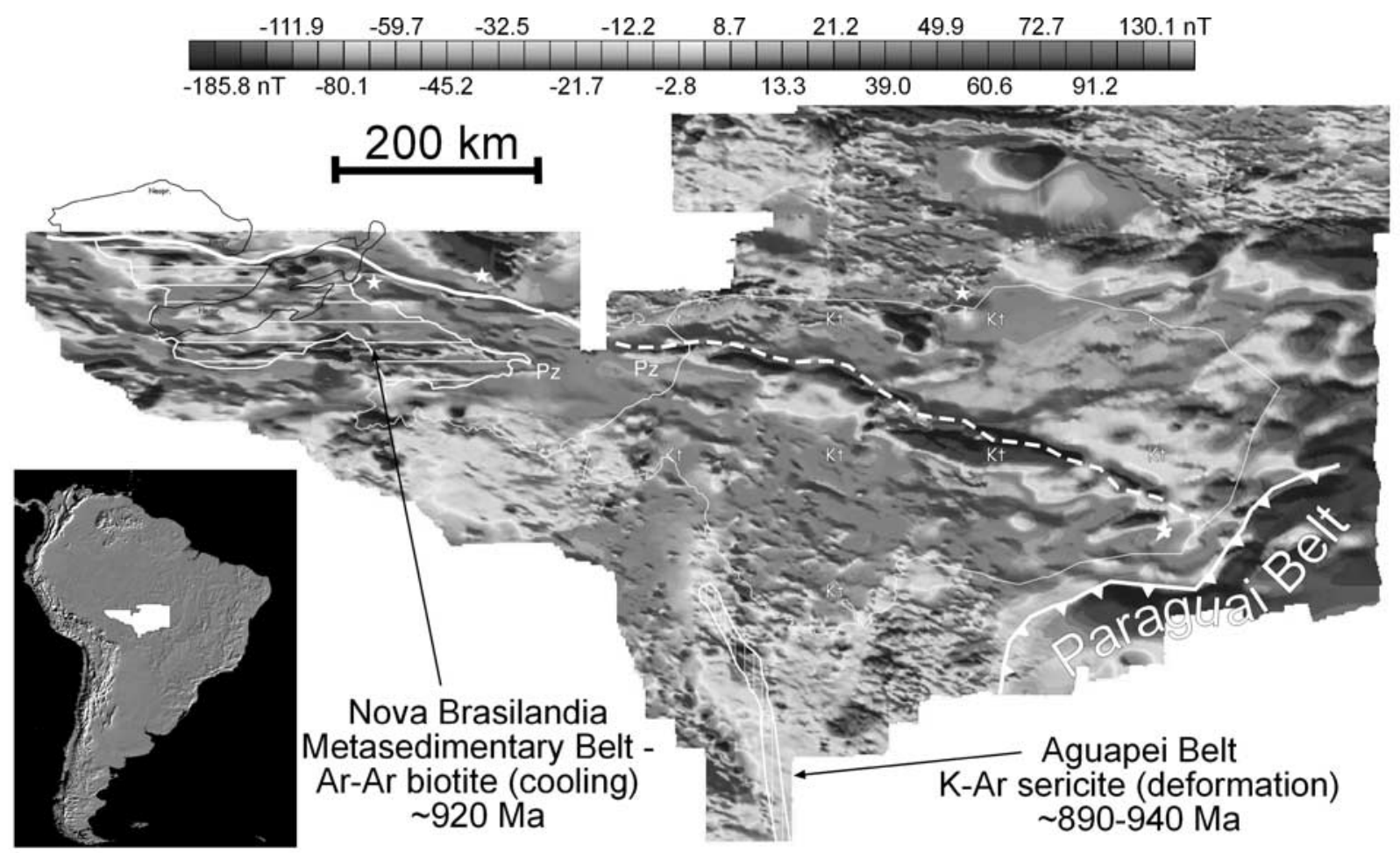

Figure 11. Aeromagnetic anomaly data for the SW Amazon craton. The Nova Brasilândia trend is marked by a clear $1000 \mathrm{~km}$ long anomaly that is covered in the eastern extent by the Paleozoic sediments of the Pimenta Bueno graben (labeled $\mathrm{Pz}$ ) and Cretaceous sediments of the Parecis Formation (labeled $\mathrm{Kt}$ ). Locations of known kimberlite pipes are designated with white stars [Companhia de Pesquisa de Recursos Minerais, 1983a, 1983b, 1983c; ENCAL, 1989; GEOMAG, 1995, 1996; PROSPEC, 1978$].$ (ENCAL report is archived in SEDOC/PETROBRAS headquarters in Rio de Janeiro under registration number 103-07407; GEOMAG [1995] report is archived in the SEDOC/GEREX/E\&P headquarters in Rio de Janeiro under registration number 101-09824; GEOMAG [1996] report is archived in the $\mathrm{SEDOC/GEREX/E \& P} \mathrm{headquarters} \mathrm{in} \mathrm{Rio} \mathrm{de} \mathrm{Janeiro} \mathrm{under} \mathrm{registration} \mathrm{number} \mathrm{101-09974.)} \mathrm{See} \mathrm{color}$ version of this figure at back of this issue.

aulacogenic origin, on the basis of stratigraphic columns that are symmetrical with respect to the central axis of the basin, as well as paleocurrent analysis that demonstrates initial transport toward the central axis [Saes, 1999]. U-Pb ages for detrital zircons for both the Nova Brasilândia and Aguapeí sequences do permit the proposed correlation, with maximum ages of deposition constrained to $1215 \pm 20 \mathrm{Ma}$ and $1231 \pm 14 \mathrm{Ma}$, respectively [Santos et al., 2000]. However, these temporal limits do not serve as prima facie proof of a geographic connection between the two belts. Given the clear differences in tectonic setting between the Nova Brasilândia sediments (calcareous turbidites and greywackes) and the Aguapeí sediments (quartzitic conglomerates and arenites), we are convinced that the correlation is unwarranted.

[28] The effects of collisional tectonics registered in the NBMB suggest a different scenario for the deposition of the Nova Brasilândia protolith. In contrast with the symmetrical rifting and passive tectonic setting implied above, an alternative model is that the sediments register basin formation in response to an active tectonic environment, either as a foreland basin or as a transtensional basin in a strike-slip environment. In the former case, an orogen-parallel basin responding to crustal loading in advance of a foreland thrust belt would be filled with sediments shed from tectonically uplifted regions. In this model, the burial and metamorphism of the Nova Brasilândia flysch deposits marks the closing of the foreland basins in the final phases of collision. We prefer the second model for the deposition of the Nova Brasilândia protolith sequence, drawing support from observations of sinistral strike-slip deformation that affected the Amazon craton at $1.18-1.15 \mathrm{Ga}$ as well as the transpressional elements (thrust sheets coupled with sinistral strike-slip faults) in the younger deformational history of the NBMB itself. In this model, strike-slip motion past an irregular cratonic margin marked by promontories and reentrants would result in alternating episodes of transpression and transtension (Figure 12). Thus the opening of the Nova Brasilândia seaway can be interpreted as a transtensional phase marking the passage of the Amazon craton past the southeastern promontory of Laurentia resulting in the development of a large releasing bend (Figure 12). The subsequent collision of 


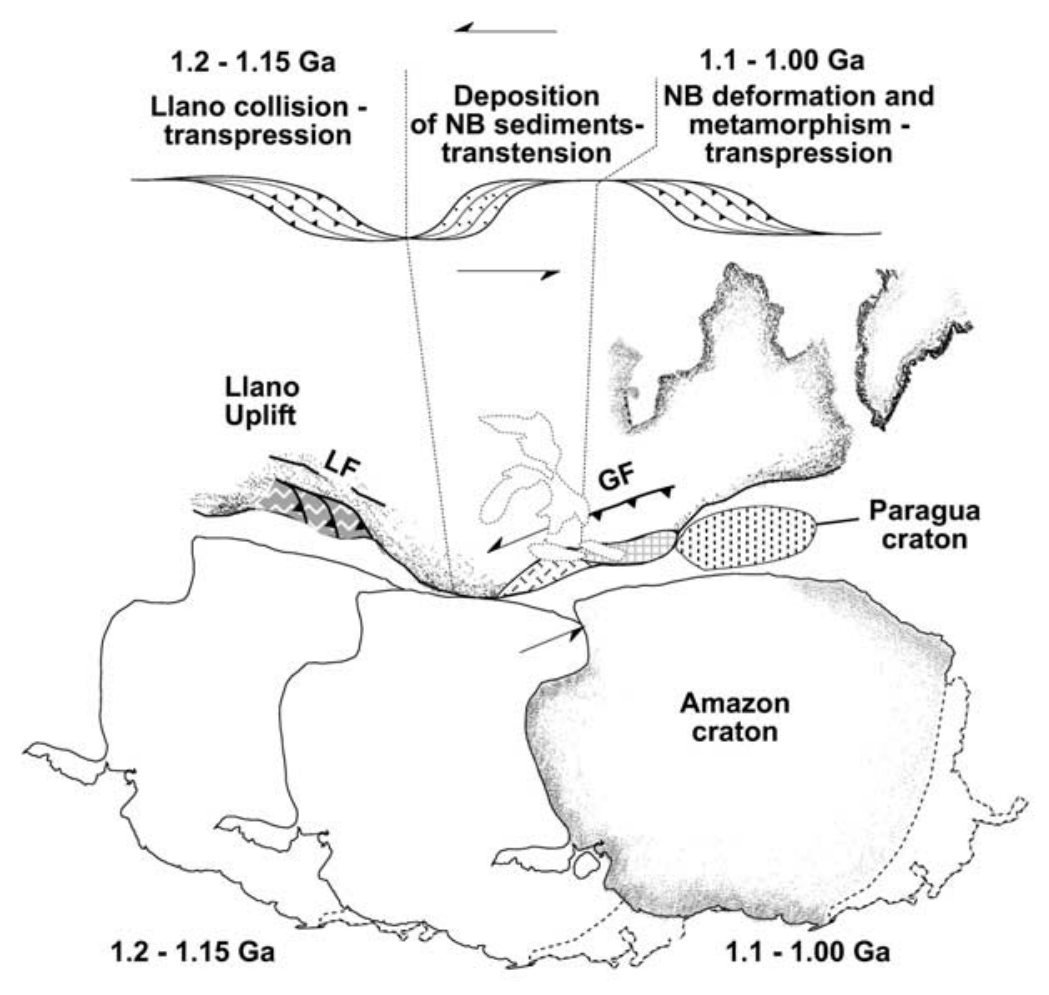

Figure 12. Schematic diagram in map view illustrating the alternating phases of transpression and transtension experienced by the Amazon craton in its Grenville interaction with Laurentia. Strike-slip motion of the Amazon craton past Laurentia began with a collision with the southern portion of Laurentia (Llano Uplift region) and proceeded with motion past the SE promontory of the North American craton, resulting in the development of a large releasing bend in the orogenic framework. The Sunsás/Grenville belt lies between the Paragua craton and Laurentia with the Nova Brasilândia belt separates the former from the Amazon craton.

the Amazon craton with the greater Paragua craton (i.e., basement rocks on both sides of the Aguapeí aulacogen) resulted in the crustal thickening and metamorphism observed at circa $1.09 \mathrm{Ga}$. In contrast, if the Aguapeí belt is a closed aulacogen, the Paragua craton extend much farther to the east, terminating in the Brasiliano-aged Paraguai belt.

[29] Given the proposed tectonic links between Amazonia and Laurentia, the tectonic history of the "Grenvillian" margin of Amazonia has implications for Rodinia paleogeography. The strike slip mylonitic shear zones preserved on the Amazon side and the recent discovery of Grenvillian terranes with Transamazonian igneous ages within the present-day SE Appalachians [Carrigan et al., 2003] suggest a complex Amazonia-Laurentia configuration. The reconstructed orogen is marked by both strike-slip faults and high-grade thrust faults, characteristic of a transpressive evolution. The evolving configuration between Amazonia and Laurentia requires fewer cratonic elements than a static, postcollisional geometry to account for $\sim 3000 \mathrm{~km}$ of Grenvillian deformation along the eastern margin of Laurentia. Thus models which call for the involvement of the Kalahari or Rio de Plata cratons along the Grenville margin of Laurentia may not be justified. We note that motion between Amazonia and Laurentia does not affect the position of Baltica opposite the Labrador margin, whose role in "Grenvillian" history and position within Rodinia is supported on the basis of both geological [Gower et al., 1990] and paleomagnetic observations [Weil et al., 1998].

\section{Conclusions}

[30] The Nova Brasilândia belt in the SW portion of the Amazon craton comprises deep-water sediments (turbiditic greywackes and marls) and two intrusive granite suites. The lithologies and structural trends of the belt are distinct from the polymetamorphic granitoids that make up the Amazon basement to the north. Petrological observations coupled with geochronological data from different isotopic systems confirm that metasedimentary rocks exposed in the Nova Brasilândia belt equilibrated at midcrustal levels at circa $1.09 \mathrm{Ga}$. Structural data from the deformed belt suggest that metamorphism resulted from crustal thickening in a transpressional zone, with strain partitioned between thrust sheets and sinistral, strike-slip faults. Regional aero- 
magnetic anomaly data and geochronological data indicate a linear E-W trend for the NBMB extending for $\sim 2000 \mathrm{~km}$, as well as a limit to the basement rocks of the craton. These observations are interpreted to indicate the location of the Amazon cratonic margin during Mesoproterozoic times. One consequence of this is that models of the Amazon craton where basement age provinces are correlated across the Nova Brasilândia belt [e.g., Tassinari and Macambira, 1999; Tassinari et al., 2000; Santos et al., 2000; Geraldes et al., 2001] need to be reevaluated.

[31] We propose a new tectonic scenario for the deposition of the Nova Brasilândia sediments into a large releasing bend of a dominantly strike-slip margin between Amazonia and southernmost Laurentia. This deposition postdates the original collision between these cratons at circa 1.2 Ga and is reflective of a transtensional phase in the ongoing northward motion of Amazonia past Laurentia. High-grade metamorphism from crustal thickening and granite emplacement marks the suturing of the Paragua block to the (present-day) southern margin of the Amazon craton in latest Mesoproterozoic times (circa 1.09 Ga). As such, the Nova Brasilândia belt marks the limits of the Amazon craton for most of the Mesoproterozoic, a fact that must be taken into account for Rodinia reconstructions for this time period.

[32] Acknowledgments. Funds for the completion of fieldwork were received from a student grant from the Geological Society of America, the Turner Fund of the University of Michigan, and the Stichting Dr. Shurmannfonds and analytical support from the U.S. National Science Foundation (EAR 0230059). U-Pb laboratory work in Germany was completed with the benefit of a fellowship from the Deutscher Akademischer Austauschdienst. Marcus Johnson and Chris Hall are thanked for their help in the University of Michigan ${ }^{40} \mathrm{Ar}{ }^{\beta 9} \mathrm{Ar}$ laboratory. Helpful reviews by Randy Van Schmus, Kent Condie, and Associate Editor David Evans improved the final manuscript.

\section{References}

Almeida, F. F. M., and Y. Hasui (1984), O embasamento da plataforma Sul Americana, in O Precambriano do Brasil, edited by F. F. M. Almeida and Y. Hasui, Ed. Edgard Blücher, São Paulo.

Alvarenga, C. J. S., and R. Trompette (1993), Evolução tectônica Brasiliana da Faixa Paraguai: A estruturação da região de Cuiabá, Rev. Bras. Geocienc., 23, $18-30$.

Alvarenga, C. J. S., C. A. V. Moura, P. Gorayeb, P. S. Sousa, and F. A. M. Abreu (2000), Paraguay and Araguaia belts, in Tectonic Evolution of South America: 31st International Geological Congress, Rio de Janeiro, Brazil, August 6-17, 2000, edited by U. G. Cordani, E. J. Milani, and A. Thomaz Filho, pp. 183-193, Fundo Setorial do Pet. e Gás Nat. (FINEP), Rio de Janeiro.

Amaral, G. (1974), Geologia Pré-Cambriana da região Amazônica, Ph.D. thesis, 144 pp., Univ. de São Paulo, São Paulo.

Bahia, R. B. C. (1997), A Formação Palmeiral (Proterozóico Superior) na Serra dos Pacaás Novos, Oeste de Rondônia, MSc. thesis, 83 pp., Univ. Fed. Pará, Belém, Brazil.

Bahia, R. B. C., and C. R. Silva (1998), Programa levantamento geológicos básicos do Brasil, Rio Pardo, Folha SC.20-Z-C-VI, 120 pp., Co. de Pesquisa de Recursos Minerais, Brasilia.

Barros, A. M., R. H. Silva, O. R. F. Cardoso, F. A. Freire, J. J. Souza, M. Rivetti, D. S. Luz, R. C. Barros Palmeira, and C. C. G. Tassinari (1978), Folha SD.21 Cuiabá, Projeto RADAMBRASIL, vol. 26, pp. 25-176, Dep. Nac. de Producao Mineral, Rio de Janeiro.

Bettencourt, J. S., T. C. Onstott, T. de Jesus, and W. Teixeira (1996), Tectonic interpretation of ${ }^{40} \mathrm{Ar} /{ }^{39} \mathrm{Ar}$ ages of country rocks from the central sector of the Río Negro-Juruena Province, southwest Amazonian craton, Int. Geol. Rev., 38, 42-56.

Bettencourt, J. S., R. M. Tosdal, W. B. Leite, and B. L. Payolla (1999), Mesoproterozoic rapakivi granites of the Rondônia tin province, southwestern border of the Amazonian Craton, Brazil: Reconnaissance $\mathrm{U}-\mathrm{Pb}$ geochronology and regional implications, Precambrian Res., 95, 41-67.

Bohlen, S. R., and E. J. Essene (1977), Feldspar and oxide thermometry of granulites in the Adirondack Highlands, Contrib. Mineral. Petrol., 62, 153-169.

Bond, G. C., P. A. Nickeson, and M. A. Kominz (1984), Breakup of a supercontinent between $625 \mathrm{Ma}$ and $555 \mathrm{Ma}$; new evidence and implications for continental histories, Earth Planet. Sci., Lett., 70, 325-345.
Carrigan, C. W., C. F. Miller, P. D. Fullagar, B. R. Bream, R. D. Hatcher, and C. D. Coath (2003) Ion microprobe age and geochemistry of southern Appalachian basement, with implications for Proterozoic and Paleozoic reconstructions, Precam brian Res., 120, 1-36.

Companhia de Pesquisa de Recursos Minerais (1983a), Projeto Serra dos Parecis, in Ministério das Minas e Energia, Departamento Nacional da Produção Mineral, Relatório Final, vols. I and II, anexos I and II, Rio de Janeiro. (Reproduced in Brazil Airborne Radiometric Mapping Project (BARMP), technical report and survey atlas, Geol. Surv. of Can., Ottawa, 1997.)

Companhia de Pesquisa de Recursos Minerais (1983b), Projeto Pacaás Novos, in Ministério das Minas e Energia, Departamento Nacional da Produção Mineral, Relatório Final, vols. I and II, anexos I and II, Rio de Janeiro. (Reproduced in Brazil Airborne Radiometric Mapping Project (BARMP), technical report and survey atlas, Geol. Surv. of Can., Ottawa, 1997.)

Companhia de Pesquisa de Recursos Minerais (1983c), Projeto Rio do Sangue, in Ministério das Minas e Energia, Departamento Nacional da Produção Mineral, Relatório Final, vols. I and II, anexos I and II, Rio de Janeiro. (Reproduced in Brazil Airborne Radiometric Mapping Project (BARMP), technical report and survey atlas, Geol. Surv. of Can., Ottawa, 1997.)

Cosca, M. A., J. F. Sutter, and E. J. Essene (1991) Cooling an inferred uplift/erosion of the Grenville orogen, Ontario: Constraints from ${ }^{40} \mathrm{Ar} /{ }^{39} \mathrm{Ar}$ geochronology, Tectonics, 10, 959-977.

Dalziel, I. W. D. (1991), Pacific margins of Laurentia and East Antarctica-Australia as a conjugate rift pair: Evidence and implications for an Eocambrian supercontinent, Geology, 19, 598-601.

Davidson, A. (1998), An overview of the Grenville Province, Canadian Shield, in Geology of the Precambrian Superior and Grenville Provinces and Precambrian Fossils in North America, Geol. Can., vol. 7, pp. 205-270, Geol. Surv. of Can., Ottowa.

Dutrow, B. L., and M. J. Holdaway (1989), Experimental determination of the upper thermal stability of Fe-staurolite + quartz at medium pressures, J. Petrol., 30, 229-248.

ENCAL (1989), Projeto Aeromagnetométrico Bacia dos Parecis, Relatório Final de Aquisição e Processamento de Dados, vol. 9, Pet. Bras., Rio de Janeiro.
England, P. C., and A. B. Thompson (1984), Pressuretemperature-time paths of regional metamorphism, part I, Heat transfer during the evolution of regions of thickened continental crust, J. Petrol., 25, 894928.

Fernandes, C. J. (1999), Geologia do depósito Pau-aPiques e guias prospectivos para ouro no Grupo Aguapeí, sudoeste do estado de Mato Grosso, MSc. thesis, 134 pp., Univ. Fed. Rio Grande do Sul, Porto Allegre, Brazil.

Ganguly, J., W. Cheng, and M. Tirone (1996), Thermodynamics of aluminosilicate garnet solution: New experimental data, an optimized model, and thermometric applications, Contrib. Mineral. Petrol., 126, 137-151.

GEOMAG (1995), Prospecções Aerogeofísicas, Levantamento Aeromagnetométrico e Aerogravimétrico na Bacia dos Parecis (Sub-Bacia do Alto Xingu)_Equipe EAG-01, Relatório Final de Aquisição e de Processamento de Dados, Pet. Bras., vol. 16, Rio de Janeiro.

GEOMAG (1996), Prospecções Aerogeofísicas, Levantamento Aeromagnetométrico e Aerogravimétrico na Reserva Indígena Juruena e Nordeste do Campo Novo, Relatório Final de Aquisição e de Processamento de Dados, Pet. Bras., vol. 16, Rio de Janeiro.

Geraldes, M. C., B. R. Figueiredo, C. C. G. Tassinari, and H. D. Ebert (1997), Middle Proterozoic vein hosted gold deposits in the Pontes e Lacerda region, southwestern Amazonian craton, Brazil, Int. Geol. Rev., 39, 438-448.

Geraldes, M. C., W. R. Van Schmus, K. C. Condie, S. Bell, W. Teixeira, M. Babinski, J. K. Bartley, and L. C. Kah (2001), Proterozoic geologic evolution of the SW part of the Amazonian Craton in Mato Grosso State, Brazil, Precambrian Res., 111, 91- 128 .

Gower, C. F., A. B. Ryan, and T. Rivers (1990), MidProterozoic Laurentia-Baltica: An overview of its geological evolution and a summary of the contributions made by this volume, in Mid-Proterozoic Laurentia-Baltica, edited by C. F. Gower, T. Rivers, and A. B. Ryan, Geol. Assoc. Can. Spec. Pap., 38, $1-20$.

Guidotti, C. V., and M. D. Dyar (1991), Ferric iron in metamorphic biotite and its petrologic and crystallochemical implications, Am. Mineral., 76, 161175 .

Hoffman, P. F. (1991), Did the breakout of Laurentia turn Gondwana inside out?, Science, 252, 14091412 
Holland, T. J. B., and R. Powell (1998), An internally consistent thermodynamic dataset for phases of petrologic interest, J. Metamorph. Geol., 16, $309-$ 343.

Krogh, T. E. (1994), Precise U-Pb ages for Grenvillian and pre-Grenvillian thrusting of Proterozoic and Archean metamorphic assemblages in the Grenville Front Tectonic Zone, Canada, Tectonics, 13, 963 982

Leal, J. W. L., G. H. Silva, D. B. Santos, W. Teixeira, M. I. C. de Lima, C. A. C. Fernandes, and A. Pinto (1978), Folha SC.20, Porto Velho, Projeto RADAMBRASIL, vol. 16, pp. 17-184, Dep. Nac de Producao Miner., Rio de Janeiro.

Litherland, M., and G. Power (1989), The geologic and geomorphologic evolution of Serrania Huanchaca, eastern Bolivia: The legendary "Lost World", J. S Am. Earth Sci., 2, 1-17.

Litherland, M., et al. (1986), The Geology and Mineral Resources of the Bolivian Precambrian Shield, Overseas Mem., vol. 9, 153 pp., Br. Geol. Surv. London.

Litherland, M., et al. (1989), The Proterozoic of eastern Bolivia and its relationship to the Andean mobile belt, Precambrian Res., 43, 157-174.

Luft, J. L., Jr., G. Rizzotto, F. Chemale Jr., and E. F. Lima (2000), Análise geológica-estrutural do cinturão Sunsás na região de Nova Brasilândia, sudeste de Rondônia, Rev. Pesq. Geocienc., 2, 65-78.

Mezger, K., B. A. van der Pluijm, E. J. Essene, and A. N. Halliday (1992), The Carthage-Colton mylonite zone (Adirondack Mountains, New York): The site of a cryptic suture in the Grenville Orogen?, J. Geol., 100, 630-638.

Moecher, D. P., E. J. Essene, and L. M. Anovitz (1988), Calculation and application of clinopyroxenegarnet-plagioclase-quartz geobarometers, Contrib. Mineral. Petrol., 100, 92-106.

Montes-Lauar, C. R., I. G. Pacca, A. J. Melfi, E. M. Piccirillo, G. Bellieni, R. Petrini, and R. Rizzieri (1994), The Anari and Tapirapua Jurassic formations, western Brazil: Paleomagnetism, geochemistry and geochronology, Earth Planet. Sci. Lett., $128,357-371$.

Mosher, S. (1998), Tectonic evolution of the southern Laurentian Grenville orogenic belt, Geol. Soc. Am. Bull., 110, 1357-1375.

Payolla, B. L., J. S. Bettencourt, M. Kozuch, W. B. Leite, A. H. Fetter, and W. R. Van Schmu (2002), Geological evolution of the basement rocks in the east-central part of the Rondônia Tin Province, SW Amazonian craton, Brazil: U-Pb and $\mathrm{Sm}-\mathrm{Nd}$ isotopic constraints, Precambrian Res., 119, 141-169.

PROSPEC (1978), Geologia, Prospeccões E Aerofotogrametria, Projeto Cabeceiras do Rio Guaporé, relatório final, texto e anexos, Minist. das Minas e Energia, Dep. Nac. da Produção Mineral, Co. de Pesquisa de Recursos Minerais, Rio de Janeiro. (Reproduced in Brazil Airborne Radiometric Mapping Project (BARMP), technical report and survey atlas, Geol. Surv. of Can., Ottawa, 1997.)

Rizzotto, G. J. (1999), Petrologia e geotectônia do Grupo Nova Brasilândia, Rondônia, MSc. thesis, 131 pp., Univ. Fed. Rio Grande do Sul, Porto Allegre, Brazil

Rizzotto, G. J. (2001), Reavaliação do ciclo orogênico Sunsás/Aguapeí no sudoeste do craton Amazônico, paper presented at Workshop of the SW Amazonian Craton: State of the Art, Univ. de São Paulo, São Paulo, Brazil, August 10-12.

Rizzotto, G. J., F. Chemale, E. F. de Lima, R. Van Schmus, and A. Fetter (1999), Sm/Nd and U/Pb isotopic data for the Nova Brasilândia metaplutonic metavolcanosedimentary sequence, Rondônia, in paper presented at the 70th Meeting of the Brazilian Geological Society, Salvador, Brazil.

Sadowski, G. R., and J. S. Bettencourt (1996), Mesoproterozoic tectonic correlations between eastern Laurentia and the western border of the Amazon craton, Precambrian Res., 76, 213-227.

Saes, G. S. (1999), Tectonic and paleogeographic evolution of the Aguapeí aulacogen $(1.2-1.0 \mathrm{Ga})$ and the basement terranes in the southern Amazon craton, Ph.D. thesis, 135 pp., Univ. de São Paulo, São Paulo.

Santos, J. O. E., L. A. Hartmann, H. E. Gaudette, D. I Groves, N. J. Mcnaughton, and I. R. Fletcher (2000), A new understanding of the provinces of the Amazon craton based integration of field mapping and $\mathrm{U}-\mathrm{Pb}$ and $\mathrm{Sm}-\mathrm{Nd}$ geochronology, Gondwana Res., 3, 454-488.

Santos, J. O. E., G. A. Rizzotto, L. A. Hartmann, N. J. McNaughton, and I. R. Fletcher (2001), Ages of sedimentary basins related to the Sunsás and Juruena orogenies, southwest Amazon craton established by zircon U-Pb geochronology, paper presented at Workshop of the SW Amazonian Craton: State of the Art, Univ. de São Paolo, São Paulo, Brazil, August 10-12.

Scandolara, J. E., and G. J. Rizzotto (1998), Programa Levantamento Geológicos do Brasil Paulo Saldanha, Folha SC.20-Z-C-V, Estado de Rondônia-Escala 1:100,000, 140 pp., Co. de Pesquisa de Recursos Minerais, Brasilia

Scandolâra, J. E., G. J. Rizzotto, J. L. de Amorim, R. B. C. Bahia, M. L. Quadros, and C. R. da Silva (1999), Geological map of Rondônia 1:1,000,000. Co. de Pesquisa de Recursos Minerais, Brasilia.

Svisero, D. P. (1995), Distribution and origin of diamonds in Brazil: An overview, J. Geodyn., 20, $493-514$.
Tassinari, C. C. G., and M. J. B. Macambira (1999), Geochronological provinces of the Amazonian craton, Episodes, 22, 174-182.

Tassinari, C. C. G., J. S. Bettencourt, M. C. Geraldes, M. J. B. Macambria, and J. M. Lafon (2000), The Amazonian craton, in Tectonic Evolution of South America: 31st International Geological Congress, Rio de Janeiro, Brazil, August 6-17, 2000, edited by E. J. Milani and A. Thomaz Filho, pp. 41-95, Fundo Setorial do Pet. e Gás Nat. (FINEP), Rio de Janeiro.

Thomas, W. A., and R. A. Astini (1996), The Argentine Precordillera: A traveler from the Ouachita embayment of North American Laurentia, Science, 273, $752-757$

Thompson, A. B. (1976), Mineral reactions in politic rocks 2, calculations of some P-T-X (Fe-Mg) phase relations, Am. J. Sci., 276, 425-454.

Tohver, E., B. A. van der Pluijm, R. Van der Voo, G. Rizzotto, and J. E. Scandolara (2002), Paleogeography of the Amazon craton at $1.2 \mathrm{Ga}$ : Early Grenvillian collision with the Llano segment of Laurentia, Earth Planet. Sci. Lett., 199, $185-$ 2000

Valley, J. W. (1992), Granulite processes driven by magmatic processes in the deep crust, Earth $\mathrm{Sci}$. Rev., 32, 145-146.

Weil, A. B., R. Van der Voo, C. Mac-Niocaill, and J. G. Meert (1998), The Proterozoic supercontinent Rodinia: Paleomagnetically derived reconstruction for 1100 to $800 \mathrm{Ma}$, Earth Planet. Sci. Lett., 154, $13-24$.

Wilding, M. C., B Harte, and J. W. Harris (1991), Evidence for a deep origin of São Luis diamonds, in Extended Abstracts of the 5th International Kimberlite Congress, Spec. Publ., 2/91, pp. 456-458, Co. de Pesquisa de Recursos Minerais, Brasilia.

E. Essene and B. van der Pluijm, Department of Geological Sciences, University of Michigan, 2534 C. C. Little Building, Ann Arbor, MI 48109-1063, USA

K. Mezger, Institut für Mineralogie, Universität Münster, Corrensstrasse. 24, D-48149 Münster, Germany.

G. Rizzotto and J. Scandolara, Companhia de Pesquisas de Recursos Minerais (CPRM), Av. Lauro Sodré 2561, Porto Velho, RO, Brazil 78904-300.

E. Tohver, Instituto de Geociências (GMG), Universidade de São Paulo, Rua do Lago, 562, Cidade Universitária, 05508-900 São Paulo, SP Brazil. (etohver@usp.br) 


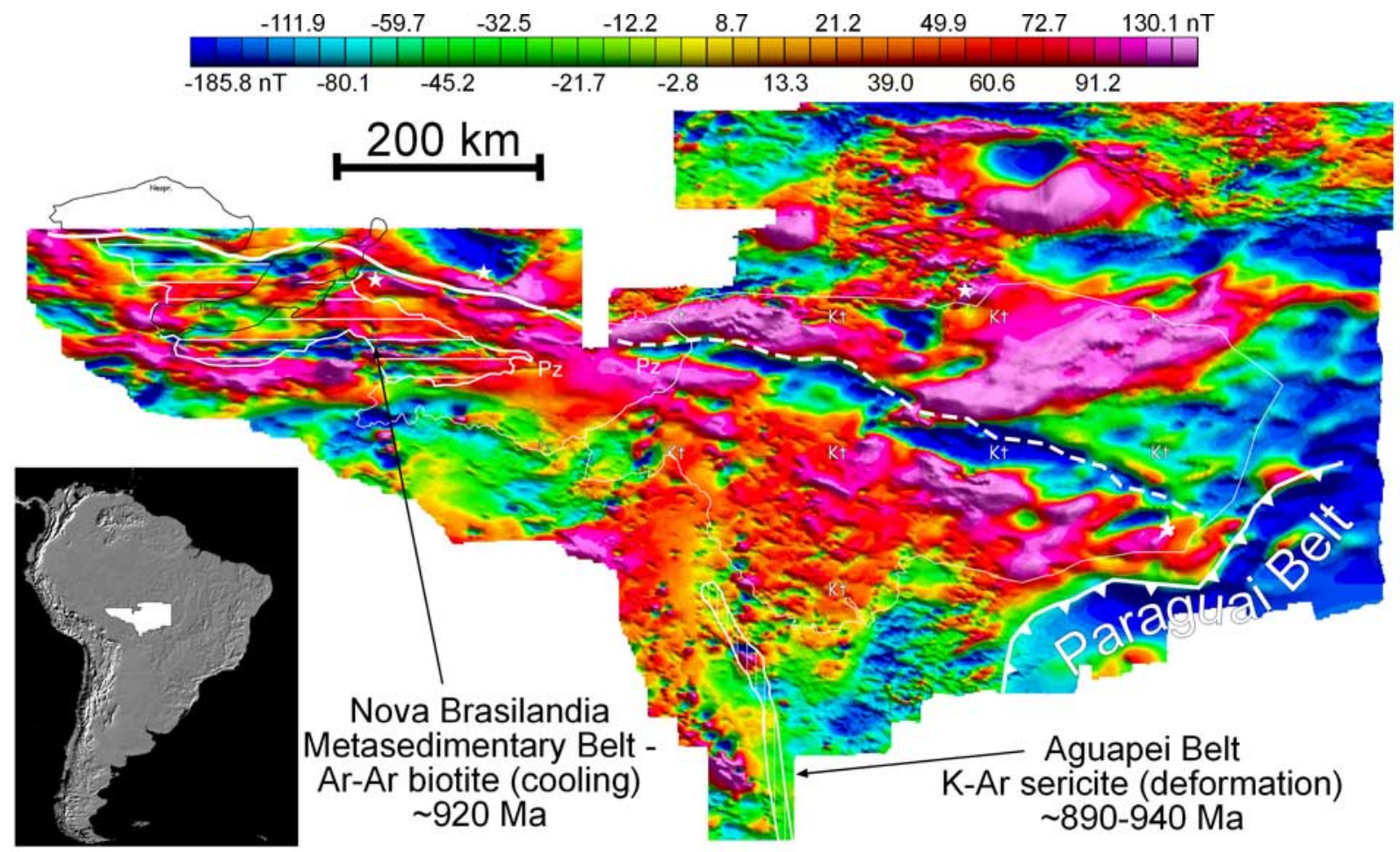

Figure 11. Aeromagnetic anomaly data for the SW Amazon craton. The Nova Brasilândia trend is marked by a clear $1000 \mathrm{~km}$ long anomaly that is covered in the eastern extent by the Paleozoic sediments of the Pimenta Bueno graben (labeled Pz) and Cretaceous sediments of the Parecis Formation (labeled $\mathrm{Kt}$ ). Locations of known kimberlite pipes are designated with white stars [Companhia de Pesquisa de Recursos Minerais, 1983a, 1983b, 1983c; ENCAL, 1989; GEOMAG, 1995, 1996; PROSPEC, 1978]. (ENCAL report is archived in SEDOC/PETROBRAS headquarters in Rio de Janeiro under registration number 103-07407; GEOMAG [1995] report is archived in the SEDOC/GEREX/E\&P headquarters in Rio de Janeiro under registration number 101-09824; GEOMAG [1996] report is archived in the SEDOC/GEREX/E\&P headquarters in Rio de Janeiro under registration number 101-09974.) 